\title{
Piri-Muridi in the Twin Cities of Islamabad and Rawalpindi, Pakistan
}

\author{
David Hansen \\ Centre for International and Strategic Analysis, Oslo
}

\begin{abstract}
Sufism, piri-muridi, in Pakistan is an overlooked aspect of Muslim religious experience. This article sheds light on how respondents of the Twin Cities of Islamabad and Rawalpindi, Pakistan, relate to this overlooked aspect, and tries to situate changes to piri-muridi in a historical context. As this article finds, being orthodox does not necessarily hinder adherence to piri-muridi. Rather, people of all sects, and even non-Muslims, regularly attend 'urs, keep a relationship with a pir, or visit the shrines on occasions - as ways of exhausting all possibilities to find comfort, seek spirituality, or solve practical problems in their lives. This aspect, then, breaks down the apparent divide between the orthodox and the traditional in the sense that many people pick bits and pieces and make those pieces into their own practiced form of Islam. Yet, piri-muridi in the Twin Cities is experiencing a purification process where its opponents try their best to discredit it as 'un-Islamic', and its adherents are often critical of certain practices and rituals but still obey it.
\end{abstract}


Keywords: Pakistan, Islam, Sufism, piri-muridi, orthodoxy, Islambad, Rawalpindi

\section{Exploring piri-muridi in the Twin Cities}

In the midst of the contemporary debate and focus on Islam, often revivalist or orthodox versions and not least the extremist version(s) of it, there is a tendency to overlook the fact that many people still relate to ancient beliefs and practices commonly associated with Sufism. In Pakistan, these popular Sufi practices are often labeled piri-muridi - which refers to the relationship between a saint $(\text { pir })^{1}$ and the disciple (murid). Instead, the focus is almost entirely on 'High Islam', the revivalist or orthodox version as propagated by Islamists, as Frembgen (2008: 4) notes:

In the Western media, Islam is almost exclusively identified with its official, scriptural, normative manifestation - orthodox, legalistic Islam. The significance of folk Islam in local contexts as well as other facets, dimensions and sub-regimes of this world religion which exist in parallel, especially the popular face of the Sufi tradition and the closely related veneration of saints, is either underestimated or ignored.

The basis for this article is my $\mathrm{PhD}$ research - which combined aspects of Islam, Islamism (shari'a), radical Pakistan, and aspects of 'folk Islam' or Sufism. ${ }^{2}$ I thus had the unique opportunity to treat 'the

\footnotetext{
${ }^{1}$ In accordance with the teachings of Islam, there can be no more prophets; humankind (still) requires spiritual guides and guardians. Thus, for this purpose, God has chosen saints, walis (friends of God) in order to watch over the world. In Pakistan, these saints are commonly referred to as pirs. Sufism was initially brought to the subcontinent by individual pirs, and after the thirteenth century, larger congregations, orders or brotherhoods, tariqas, started arriving (Ewing 1983: 254-5; Frembgen 2008: 18). Shaykh is also a word used with similar meaning to that of pir (Rozehnal 2006: 30), mostly in Arabic-speaking countries. Frembgen (2008) notes that the ideal of all Sufi saints is to be able to trace their lineage back to the Prophet Muhammad. In Pakistan, many pirs cannot claim to do so (p. 17).

${ }^{2} \mathrm{PhD}$ dissertation titled "Radical Rhetoric-Moderate Behavior: Perceptions of Islam, Shari' $a$, and the Radical Dimension among Inhabitants of Islamabad and Rawalpindi in the post-9/11 Pakistani Reality." The dissertation was submitted to the University 11 June 2010 and publicly defended 11 November 2010. The evaluation committee consisted of Dr. Stephen Cohen (Brookings Institute), Prof. Tor H. Aase (University of Bergen), and Prof. Pamela Price (University of Oslo). Data for the study were
} 
popular face of the Sufi tradition' alongside normative (Islamist) manifestations of Islam. In this fusion, I found some surprising responses and conclusions - which questions Sufism as (only) the 'path of love'. I quite often found the path to be quite orthodox and even take on a radical rhetorical outlook. My focus is not on the intellectual aspects of piri-muridi, although I do take into account any such reflections from my interviewees. Rather, in this article I will shed light on popular practices associated with piri-muridi as I find it important to convey what is happening in the current religious climate in Pakistan - not least owing to the seemingly adverse developments in the recent decades, which has led to a focus on (only) radical and extremist interpretations of religion.

Perhaps because of the lack of focus on 'folk Islam', there has been created an impression that Sufism may serve as an opposing force to the increasingly revivalist, orthodox, and even radical and extremist tendencies found in Pakistan. This impression, which has been created by the media and certain scholarly works alike, stands almost unchallenged, and may not be true for Pakistani urban centers like Islamabad and Rawalpindi (hereafter the Twin Cities). As I have found, and will shed light on in this article, many people in Pakistan do relate to piri-muridi in many aspects of their lives and blend it with their knowledge of Islam - making it their practiced form of religion. Yet, urban Islam as I found it in the Twin Cities is experiencing a shift towards an orthodox or revivalist form of Islam, often wrapped in Deobandi or Wahhabi packages, which has more focus on shari' $a$ and condemns many of the practices commonly found in piri-muridi in Pakistan, whilst adhering to others. This resembles part of Gellner's (1978) 'Pendulum Swing Theory of Islam', in the sense that there is an increasing transfer of loyalty from the traditional 'folk Islam' (Sufism) towards a purist and scripturalist version of Islam. ${ }^{3}$ It should, however, be emphasized that the transfer of loyalty is not necessarily

gathered through approximately 18 months of sequential fieldwork, wherein I relied on passive and participant observations, formal and informal interviews, and conducted two surveys $(\mathrm{N}=475 * 2)$. I also relied on my study/research experiences in Pakistan the last decade. All tables and pictures in this article have been collected and processed by the author.

${ }^{3}$ Gellner (1978), also see Hassan (2004: 13-4, 78, 120) for elaborative accounts on Gellner's theory. I will not describe the shift as a 'pendulum swing', as I do not necessarily believe that the pendulum will turn back towards what may be seen as the traditional 'folk Islam' of the past. 
absolute but rather selective. This, again, differs itself from the perception of Sufism as mystical, ecstatic, joyous, and perhaps more importantly; anti-shari'a version of Islam.

The majority of the people whom I interacted with in the Twin Cities mostly expressed ambivalence towards Sufism, often condemning some of its practices and rituals, while embracing and adhering to others. Recitations of poetry or other in-depth intellectual expressions on the issue were mostly absent. During my fieldwork, I became increasingly convinced that Sufism in Pakistan is just as related to culture as it is to religion - the South Asian spices blended into one big 'melting pot' - and the result of that is a specific South Asian approach to ritualistic behavior towards religion, which sometimes surpasses religious and sectarian demarcation lines. Moreover, this culture is so deeply rooted in many people's lives that it is hard to assess where religion ends and culture begins.

I now turn to a few paragraphs describing how the two main Muslim sects in Pakistan, the Barelvis and the Deobandis, relate to piri-muridi in general terms and on an overall level.

\section{The sectarian divide and piri-muridi}

The Deobandis take their name from the town in which the sect was founded in 1867, Deoband in India. The Deobandi movement's founders were Muhammad Qasim Nanantvi [1833-1877] and Rashid Ahmad Gangohi [1829-1905]. The Deobandi movement's aim was to sustain a reformed Sunni Islam separate from the colonial state of India. In 1867, the reformist movement opened up a school in Deoband, India, in order to educate and promote their aim through the curriculum of studies of the Qur'an, the Prophet's praxis (Sunnah, as found in collections of his narrations: hadiths collections) and Islamic law and science. Contemporary Deobandis are increasingly influenced by the Saudi Arabian Wahhabi doctrine, and as among the Wahhabis, there exists a general theoretical objection to the worshipping of Sufi pirs, although individual Deobandis do follow the tradition of various Sufi orders, and emphasize individual spiritual discipline through spiritual masters. ${ }^{4}$ Concerning this aspect, Ewing (1983: 254) notes

${ }^{4}$ Abbas (2005: 103, 112); Ahmad (2008: 67); Cohen (2005: 180); Mohammad (2002: 221-2); Rahman (2007: 124); Talbot (2005: 148); Ewing (1983: 254). 
that early Deobandis sought to, “...combine the roles of pir and 'alim, espousing a doctrine according to which individual was to look to a single 'alim as his definitive guide to religious law." In this context, Rahman (2007: 124) adds that the Deobandis "...did not oppose mysticism altogether, but did argue that adherence to the Islamic law (Sharia) was the path to mystical exaltation." I will return to how I found the stance towards piri-muridi among Deobandis in the Twin Cities later in the article.

The Barelvi sect takes its name from the place of its origin, Bareilly in India, where it was founded by Ahmad Reza Khan [18561921] as an opposition movement against the reformists, such as the Deobandis, towards the end of the 19th century. ${ }^{5}$ In contemporary Pakistan, Barelvis have the greatest number of followers among the Muslim sects. ${ }^{6}$ The Barelvis adhere to a system of Sufi and syncretic folk traditions, and attach great importance to Sufi saints (pirs), whom they treat as intercessors before God. For Barelvis, the Prophet Muhammad is treated with the utmost veneration and is attributed an almost divine status, and celebration of the Prophet's birthday, milad an-nabi, has become a favored and popular event. ${ }^{7}$ Another feature of Barelvis is their veneration of saints and their ancestors, which most clearly manifests itself through the celebration of late pirs through festivals on the days of their deaths; the so-called 'urs celebrations which symbolizes the 'mystical nuptial', the marriage of a pir with God. ${ }^{8}$ The Barelvis are often called the main rivals of the Deobandis because of their devotion to celebrating saints, the way the sect has maintained plural manifestations of ancient pre-Islamic religions and cultures, and the near divine status that they attribute to the Prophet Muhammad.

The Barelvis, unlike a majority of the Deobandis, supported the calls for an independent Pakistan before partition. In fact, their role in mobilizing for the new state was of tremendous significance in

\footnotetext{
${ }^{5}$ Ahmad (2008: 67); Ewing (1983: 254); Kazimi (2009: 78); Mohammad (2002: 222 3); Rahman (2007: 125); Rahman (1984: 41).

${ }^{6}$ Cohen (2005: 180).

${ }^{7}$ Ahmad (2008: 67); Ewing (1983: 254); Mohammad (2002: 223); Rahman (2007: 125); Rahman (1984: 41); Zaman (2004: 11).

${ }^{8}$ Ahmad (2008: 67); Frembgen (2008: 6); Gilmartin (1979: 486); Mohammad (2002: 223).

${ }^{9}$ Ahmad (2008: 67); Mohammad (2002: 223).
} 
various parts of pre-partition India. Sufi pirs and sajjada nashins (tenders of shrines) ${ }^{10}$ put their weight behind the Pakistan Movements by using their spiritual and, quite often, political influence. They represented a vital role in rallying for the Muslim League and the Pakistan Movement, through, for instance, rallies that were held during 'urs at different shrines. ${ }^{11}$ The Barelvi sphere of influence was traditionally strongest among rural areas of the Punjab and regions of Sindh. In later decades, however, their support base has been extended into the urban areas as well - especially among deprived and poor urban dwellers. Despite popular Western perceptions, the Barelvis, just as the Ahl-e-Hadiths and the Deobandis, view shari'a as an important and fundamental prerequisite for Pakistan. ${ }^{12}$

As will become apparent later in this article, these demarcation lines between the Barelvis and Deobandis, when relating to pirimuridi, are not absolute in practical terms. This is not only related to an increased orthodoxy among most sects, but also to the fact that people (still) have the tendency to be quite eclectic in how they view and practice religion.

I will now explain the historical origins, evolution, and organizational structure of piri-muridi in Pakistan. The purpose of this is to situate certain terms as well as to give an impression of how the institution of piri-muridi came into being in the form it takes in contemporary Pakistan.

\section{The Sufi legacy and practical make-up of the piri-muridi institution in Pakistan}

Sufism is the mystic, spiritual, or esoteric aspect or face of Islam, and in Sufism, religious experience is the essentially significant component. Sufism as such thus complements the shari'a, or external

\footnotetext{
${ }^{10}$ Sajjada nashin or gaddi nashin are regular terms used for the hereditary pirs. The literal meaning of sajjada nashin is 'he who sits on the prayer rug' (Ewing 1983: 255).

${ }^{11}$ Aziz (2001: 43-52); Hassan (1987: 560); Mohammad (2002: 223); Talbot (1999: 30, 69-70); Talbot (2004: 76). See Gilmartin (1979) for detailed accounts on the role of pirs in the Pakistan Movement.

${ }^{12}$ Mohammad (2002: 223).
} 
law (exoteric aspect). ${ }^{13}$ From the eleventh century, Sufi saints played a critical and perhaps the most significant role in spreading Islam and converting people to Islam in the subcontinent. Some even maintain that the saints enabled the 'Orthodox' Sunni Islam of the Arabian deserts to merge with the indigenous culture(s), making it acceptable for the people of South Asia at the time when Islam started to spread to the subcontinent. Later, Sufi saints were instrumental in preaching and developing popular Islam, 'folk Islam', through their missionary activities. ${ }^{14}$ Sufi centers, khanqahs, ${ }^{15}$ became an important institution in the subcontinent. These khanqahs provided Muslims as well as non-Muslims with spiritual guidance, social welfare, and education. They were in addition instrumental in various cultural activities for the public. The khanqahs had a special appeal to the public, as they represented something very different from the rigid and stratified Hindu structures in society. Instead, they focused on the equality of humankind. ${ }^{16}$

Sufism, in practical terms represented (mainly) through pirs and shrines (dargah), is an integral part of the religious organization of Pakistan. ${ }^{17}$ Those that become followers, murids, are often related to as Sufis (although they may refrain from using the term themselves) and in addition, there are the dervishes, also commonly known as faqirs. A murid or Sufi does not necessarily bear any visible signs of affinity to his pir. Dervishes and faqirs on the other hand, have a total dedication and commitment to the ideal of poverty in their spiritual journey to God; their lifestyle is for them a means to seek salvation and constitutes a kind of mystic exercise. Their lifestyle also places

\footnotetext{
${ }^{13}$ Frembgen (2008: 4); Mohammad (2002: 229); Verkaaik (2004: 69). The term 'Sufi' is derived from the word suf, wool. This is related to the practice of the early ascetics of Islam who wore frocks of rough white wool, following the example of the Prophet Muhammad (Ahmed 2003: 91; Frembgen 2008: 4; Malik 2006: 30).

${ }^{14}$ Buehler (1997: 299); Frembgen (2008: 35); Gardner (1993: 213); Hassan (1987: 553, 557); Iqbal (2007: 62); Malik (2006: 11, 31); Talbot (1999: 29).

${ }^{15}$ Dargah and mazar are also used to describe shrines. I will use the terms khanqah and dargah (interchangeably) in this article. Mazar is mostly used to describe the tomb itself in or under the pir is buried. Frembgen (2008) refers to khanqahs as lodges, which later on developed into dargah institutions. These dargah institutions would also include facilities like a mosque, communal kitchen (langar), hospital, schools - in addition to the shrine(s) of deceased pirs (p. 53).

${ }^{16}$ Hassan (1987: 555); Rozehnal (2006: 30)

${ }^{17}$ Cohen (2005: 196); Ewing (1983: 251).
} 
them on the periphery of mainstream society and distinguishes them from moderate Sufis, who are often close to an orthodox Islam. ${ }^{18}$ Frembgen (2008: 15), refers to P.M. Currie and explains the difference between a dervish and a Sufi by saying that, "A Sufi is one who tends towards the mystic life as it has developed within the framework of Islam, whereas a darvish [sic] or faqir is one who is attached full-time to the religious life either as a dependant of a Sufi establishment or as an independent wandering mendicant." Some tend to confuse the pir and the dervish, thus a distinction between these two should also be made, which Frembgen (2008: 19) describes in the following:

The shaikh, pir, ishan, etc. who usually lives permanently at a shrine is a spiritual authority who instructs disciples in mystical teachings, writes mystical treatises and poetry or propagates religious reforms. A dervish, in contrast, who tends towards renunciation, is a wanderer both on an internal spiritual path and in this exterior, earthly world. He expresses the Sufi tradition in his life by seeking proximity to God through ecstatic practices.

The hereditary successors of the pirs, the sajjada nashins, commonly referred to as (just) pirs, play the role of mediators or intercessors between their murids and God. This is made possible through the spiritual blessings (baraka) bestowed to the pir during his lifetime, and after that, transcended to the shrine itself. The shrine and its sajjada nashins thus become the (new) sources of blessings. The murids must then gain access to the original pir through the living (hereditary) pirs. ${ }^{19}$ This ritual veneration of saints and the replacement of the concept of direct contact with God, as it existed in the mysticism of early Islam and still practiced among many Muslims, developed in the subcontinent some time during the thirteenth and

\footnotetext{
${ }^{18}$ Frembgen $(2008: 2,11,14)$. The literal meaning of dervish is (one who goes) from door-to-door, i.e. a beggar or poor. Faqir means poor. Some dervishes are even venerated as saints after their deaths as people ascribe more magical than charismatic qualities to them. Certain dervishes became successors to shamans for nomadic people in Central Asia (Frembgen 2008: 14, 17, 29).

${ }^{19}$ Aziz (2001: 6); Buehler (1997: 300); Ewing (1983: 255-6); Frembgen (2008: 31); Gardner (1993: 213); Gilmartin (1979: 486-7); Hassan (1987: 557); Mohammad (2002: 229); Qureshi (2002: 36); Rozehnal (2006: 30); Talbot (1999: 29); Verkaaik (2004: 82)
} 
fifteenth centuries. ${ }^{20}$ Hassan (1987: 557) offers his explanation of the system of piri-muridi as it developed during the passage of time in the following:

With the passage of time the khanqahs, as a socioreligious organization, evolved and changed. The spirituality of the mystic and knowledge of mysticism shifted from a learned process to an hereditary one. The spiritual power of the founder of the khanqah came to be transmitted through his descendant who became the center of the devotion of followers of the Sufi saints who, after their death, were usually buried in the khanqah. This was an important change and eventually led to the development of the master-disciple, or what is known as the pir-murid [sic] paradigm in which pir (or master) is the director and murid (disciple) a faithful follower obliged to surrender himself/herself completely to the pir.

The system of piri-muridi is also a system of (hereditary) reciprocity. In this, the development of piri-muridi in Pakistan is often seen to have changed from a system where murids would spend longer periods with the pir to a system of blind devotion to the pirs. In this, there is a split from the traditional rigid system. Ewing (1983: 260) explains this aspect of reciprocity of the piri-muridi system in the following:

Historically, the importance of the shrines derives directly from the Sufi tradition, because most pirs were originally respected as Sufi masters and teachers. As the tradition has developed in South Asia, however, and in somewhat different ways in other parts of the Muslim world as well, there has been a partial split between Sufism as a rigorous spiritual discipline transmitted from spiritual teacher to qualified disciple on the one hand, and "piri-muridi" as the term is usually used, rather pejoratively, in Pakistan today, to mean a blind devotion of the lay follower (murid) to a pir, whom he expects to act as a spiritual mediator for him. Such pirs are exemplified by the traditional sajjada-nashins.

This shift, the evolution of a hereditary system of saint allegiance and not least what Ewing terms 'blind devotion of the murid to a pir', albeit as ancient as it may be, is something I found many respondents to object to, as I will explain later in the article.

${ }^{20}$ Frembgen (2008: 30). 
Whereas some look into the deeper meanings and understanding of Sufism from an intellectual perspective, for most people in Pakistan (especially among the general public in Punjab and Sindh), the usual form of worship is the contact, submission, and relationships they have with their respective pirs. ${ }^{21}$ The murids show their affection for the pirs by visiting their dargahs, sometimes offering food or other items, and in return, they receive the pirs' baraka and promises of a better life, a cure, or otherwise that their wishes may be granted. The ability to heal and bestow their murids with baraka is said to be derived from the pirs' proximity to God. In doing this, pirs rely on the tradition of curing diseases as believed to be inherited by Prophet Muhammad himself. ${ }^{22}$

Dargahs and sajjada nashins are often visited when people suffer from a mental or physical illness, when desiring wealth or success, and even in trying to eliminate a threat or a magic spell someone has put onto them. The hereditary pirs and the spirit of the deceased pirs are thus seen as intercessors before God, negotiating healing, prosperity, and good fortune on behalf of the murids. ${ }^{23}$ Often,

\footnotetext{
${ }^{21}$ Fieldwork notes. Also see Mohammad (2002: 229).

${ }^{22}$ Frembgen (2008: 17, 27-8, 31); Mohammad (2002: 229). As Mohammad (2002) notes, some of the ceremonies being conducted at dargahs all over Pakistan are reminiscent of popular Hinduism (and Sikhism) (p. 229). This is also true for the relationships that often foster between the murid and the pir - which in Hinduism is the relationship between the guru and the chelal sheshya (Frembgen 2008: 128; Mohammad 2002: 229). Gardner (1993) notes that in South Asia, pirs' efficiencies to grant requests, give blessings, are being assessed on the basis on how 'hot' a pir is; the 'hotter' the pir, the more power he is said to have (p. 215). Frembgen (2008) exemplify the extreme influence pirs have over murids when he notes that some even drink the water that the pir has cleaned himself with, swallow his saliva and sputum, and even rub dirt from his feet onto themselves (p. 31).

${ }^{23}$ Pirani (2009: 4, 35). Pirani (2009) specifically stresses that many use faith healers, saints, for curing mental illnesses and that people may even combine the use of these saints together with traditional medicine (p. 4). Pirani finds that some of the attendees she studied expressed that they experienced relief of symptoms of diseases accounted to the healing powers of the shrine and pir. It should also be noted that she found that few of the participants at the shrine were offered, or could afford, treatment for their illnesses at private facilities (p. 177, 222, 273). In analyzing the environment of the shrine, Pirani says, "What I witnessed at the Shrine was not necessarily 'religious activity' but a social play where the actor attempted to use the context of the Shrine and it's religious legitimacy, and the therapeutic milieu to create innovative solutions to their problems. For many of them, this solution extended to their home life and became instrumental in their identity." (p. 289).
} 
illnesses (of various kinds) are seen as having been 'spelled onto people,' wherein the pirs are seen as one way of remedying the illness. Regarding this, Pirani (2009: 28), who has conducted research on understandings and explanations of ill health and help-seeking among attendees at a shrine in Sindh, says the following:

Pakistani culture is a mixture of rituals, traditions, and folk beliefs. The belief system underlying causation of illness and healing regimes is complex and multilayered. Explanations of illness include possession by jinn [spirits], ghosts or fairies; evil spirits; black magic spells and healing approaches including exorcism, sorcery, faith and traditional healers including long dead Sufi saints. Often the rationale behind these beliefs is again believed to be rooted in the Qur'an and Hadith. $^{24}$

In describing how some murids experienced their connection to the shrine and how the shrine provided comfort and relief for them, Pirani (2009: 191) notes that:

The attendees described a very affectionate relationship with the dead Saint. They located the spirit of the Saint within the geographical boundaries of the Shrine. This extended the relationship with the Saint to include a relationship with the place (the Shrine). They felt listened to, taken care of, and hopeful for change in their circumstances. Many attendees described how they had found a true guide and powerful protector in the Saint and how their lives had changed completely since they had found the path to the Shrine. When they felt restless, agitated, or low, they just had to go and hold the jaali [calligraphic screens or walls surrounding the shrine] to be reminded that they were cared for.

When a pir dies, most often a son or another descendant of the family takes over the task of acting as pir. He is then given the title of sajjada nashin. The sajjada nashin then takes on the spiritual responsibilities that rested with the old pir, and is in addition seen as caretaker of the shrine and as 'inheritor' of their ancestor's baraka. This gives the sajjada nashins the authority to wield spiritual power over their

\footnotetext{
${ }^{24}$ In this context, a poll conducted by Gallup Pakistan titled Views on Evil Eye \& Magic, February 2010 , finds that $78 \%$ of Pakistanis claim to believe in both 'evil eye' and magic. Another poll conducted by Gallup Pakistan dated 16 February 2007 titled Views of Black Magic and Tawiz Ganda finds that 52\% respondents believed in black magic, kala jadu. Similarly, $49 \%$ of respondents believe that wearing an amulet (tawiz) can be used to heal ill effects of kala jadu.
} 
murids - thus, on the other hand, if the murid fails to oblige the sajjada nashin, this is thought to have adverse consequences. ${ }^{25}$ This hereditary system has led Sufism to become an 'institution' in Pakistan, wherein 'houses of pirs' have accumulated large fortunes based on the worshippers' non-taxable donations. ${ }^{26}$ The pirs are involved in many social dealings, ranging from the abovementioned activities, giving blessings at weddings, to giving advice to politicians. Pirs are parts of large networks involving the political sphere and elite of Pakistan, thus making them a political force in their own right. ${ }^{27}$

I now turn to discuss how Sufism has been subject to (instrumental) change by various political leaders in postindependence Pakistan.

\footnotetext{
${ }^{25}$ Ewing (1983: 255, 259); Mohammad (2002: 229); Talbot (1999: 29); Verkaaik (2004: 82). Abbas (2007) in his research finds that pirs even exert power over their murids by, for instance, suggesting names for children (p. 40), this is also mentioned by Frembgen (2008: 31).

${ }^{26}$ Mohammad (2002: 229). Ewing (1983) notes that sajjada nashins annually collects contributions from the tribe(s) associated with the particular shrine in a process called nazar (p. 255)

${ }^{27}$ Mohammad (2002: 229-30).
} 


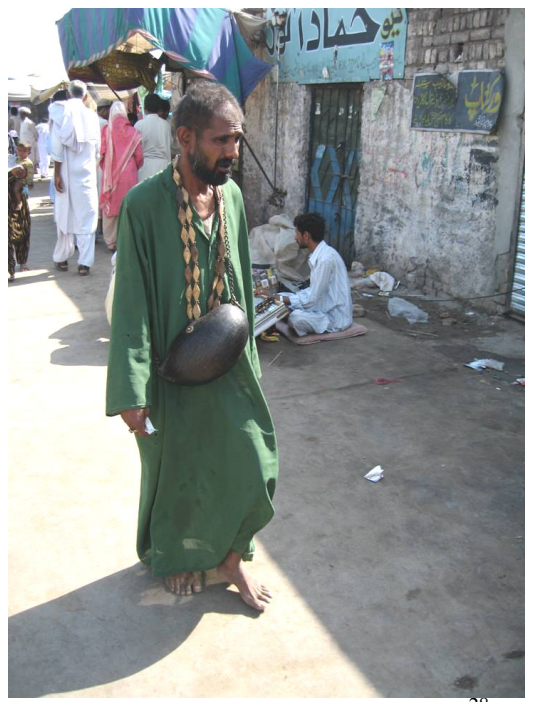

Figure 1. 'A hungry dervish's walk.'

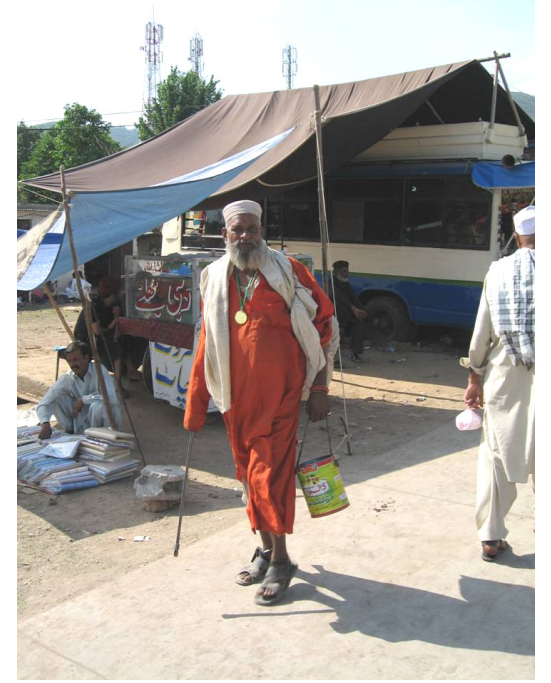

Figure 2. Traditional Sufi.

\section{'Redefining the saints'}

Ewing (1983: 251-2) finds that pirs, through the organizational structure of the shrines, have been seen as an obstacle to (governmental) political and social organization of Pakistan. Until Ayub Khan's modernist but at the same time military rule, few changes to the shrines' structure were noted. ${ }^{29}$ Ayub, and later Zulfiqar Ali Bhutto, viewed the ulama as a hindrance to modernist development of Pakistan, as the ulama desired a literal return to a system based on Islamic law (shari'a). On the other hand, the tradition of the shrines, wherein the sajjada nashins were seen as feudal

\footnotetext{
${ }^{28}$ Frembgen $(2008: 2,135)$ notes that itinerant dervishes usually carry a begging bowl (kashkul) around their necks, for collecting alms. It is said that when the bowl is carried on the back the dervish is not hungry or the bowl is full, and when carried on the stomach, the dervish is hungry. Frembgen also notes that the kashkul probably dates back to similar practices followed by itinerant Buddhist monks and Hindu ascetics (p. 135).

${ }^{29}$ Talbot (1999) notes that Ayub Khan even utilized the 'Sufi-vote' when he was able to mobilize support form the congregation of pirs, Jami'at ul-Mushaikh, in the 1965 elections (p. 30). Aziz (2001) notes that Ayub Khan is said to have been a murid of the pir of Dewal Sharif (p. 55).
} 
aristocrats hindering political control, was not compatible with their aims. Both leaders desired to identify and legitimize their rule with Islam, and thus, as an attempt to balance out the orthodoxy represented by the ulama, and perhaps as a choice between what they perceived as 'two evils', they both co-opted the shrines. ${ }^{30}$

Ayub brought along some few changes to the way shrines and the pirs attached to them were to function. He concentrated his efforts on utilizing the shrines as a vehicle in his modernization process. Instead of suppressing the shrines, as in the examples of Turkey and Saudi Arabia, Ayub co-opted them through a formal institutionalizing process of religious endowments, awqaf, with the 'West Pakistan Waqf Properties Ordinance of 1959.' This was further increased during Bhutto's era, and under Zia, was transformed into the Department of Awqaf. ${ }^{31}$ In addition to the promotion of Sufism in the amended forms that the government wanted, Ayub Khan also started building infrastructure adjacent to the shrines in order to distract attention away from the traditional power of the sajjada nashins. This infrastructure included schools, hospitals and other institutions meant for the common social welfare of the needy. Already at that time, it was apparent that this kind of infrastructure was in opposition to the sajjada nashins' powers, as they represented alternative (and traditional) remedies and cures through their ways of giving blessings thought by the public to fix their problems, which often come in the form of amulets (tawiz), spiritual guidance, and conversations. ${ }^{32}$ In this lies an important aspect in the sense that some things commonly

\footnotetext{
${ }^{30}$ Buehler (1997: 311); Ewing (1983: 253).

${ }^{31}$ Aziz (2001: 55); Buehler (1997: 310); Ewing (1983: 251-2, 258, 262); Rozehnal (2006: 35). Ewing (1983) notes that Ayub Khan initiated the process leading up to the 'West Pakistan Waqf Properties Ordinance of 1959' - which gave the central government the power to directly control and manage shrines, mosques, and other properties dedicated for religious purposes (awqaf). The 1950 ordinance was superseded by another similar ordinance in 1961, and during Zulfiqar Ali Bhutto the Auqaf Act of 1976 came into being. All ordinances and the Act were promulgated in efforts to lessen the traditional political power of both the sajjada nashins as well as the ulama. Another goal of these ordinances was to persuade the public that the government was better equipped to maintain the shrines as well as that of trying to convince them of the inability of the sajjada nashins to grant blessing over their murids (p. 258-9).

${ }^{32}$ Buehler (1997: 310-11); Ewing (1983: 261); Frembgen (2008: 32); Hassan (1987: 562). Ewing (1983) notes that the policy of supporting institutions for social welfare continued during Zia's rule (p. 264).
} 
associated with modernity, such as amenities and state organization, social welfare such as education and medical assistance, are assessed as countering the interest of the traditional institution of piri-muridi. Bhutto's emphasis on the shrines can hardly be overestimated; he utilized the shrines to convey and carry out his policies, and thus encouraged government participation in the Sufi rituals, such as the celebration of the anniversary of the death of a pir ('urs) at the shrines. ${ }^{33}$ Whereas, as Ewing (1983: 263) notes, during Ayub Khan's rule, "...participation in the 'urs by government officials was generally limited to the literary and social-welfare activities scheduled to occur in conjunction with the 'urs." During Zulfiqar Ali Bhutto's rule it became common practice that higher government official conducted some of the ritual ceremonies, such as the laying down of the cloth covering the tomb (chadar) at the beginning of an 'urs. ${ }^{34}$ Bhutto often went to rural shrines and interacted with the pirs as well as the murids, sometimes referring to himself as a faqir. ${ }^{35}$ Talbot (1999: 216) notes that Bhutto himself even came to be seen a martyred pir after his death, with thousands of people coming to his tomb every year. In modern day Pakistan, Benazir Bhutto has also been elevated to a similar status, something like a female pir, sheikha, where people regularly go to her gravesite in Larkana, Sindh, as well as the place where she was killed, Liaqat Bagh, Rawalpindi, where a makeshift memorial has been raised.

In trying to weaken the aristocratic outlook and the traditional roles as political leaders of the pirs, both Ayub and Bhutto emphasized the 'true nature' of the Sufi tradition, wherein political leadership (in theory) is separated from spiritual authority - thus, as Ewing (1983: 253) terms it, they were trying to 'redefine the saints.' This redefining was concentrated on an emphasis on the return to the roots of Sufi teachings, in order to link themselves to religious authority and legitimacy as rulers of the Muslim nation of Pakistan.

\footnotetext{
${ }^{33}$ Aziz (2001: 56); Buehler (1997: 311); Ewing (1983: 252, 263); Hassan (1987: 562); Talbot (1999: 37). Qadeer (2007) notes that during Bhutto's rule, qawwali, the musical genre made up of Sufi poetry, gained the status of national music, often being featured in films. The qawwali was embraced by large segments of the society ( $\mathrm{p}$. 246). Ahmad (2008) notes that listening to qawwali aims at getting the listeners into an ecstatic trance (p. 67).

${ }^{34}$ Ewing (1983: 263).

${ }^{35}$ Verkaaik (2004: 83).
} 
However, the reforms put in place by Ayub Khan might have worked against the desired aims of weakening their powers, instead strengthening the influence of the pirs and the sajjada nashins by recognizing their practices and by formal appointment of staff to oversee the nazar. ${ }^{36}$

With General Zia ul-Haq's coup d'état in 1977 came a (slight) shift in the government's role in co-opting the shrines. Zia was less concerned with the promotion of shrine activities, such as the yearly 'urs celebrations. ${ }^{37}$ For Zia, the religious authority sanctioned by the shrines was not particularly important, as he instead focused more on legitimizing his rule and formulating new policies with the assistance of the ulama. The ulama, the Deobandi ulama in particular, resisted the idea of pirs and shrines and the traditional relationship between the pir and the murid, and saw no difference between the exoteric and esoteric aspects of religion, thus arguing that there was no ambiguity between shari'a and Sufism. ${ }^{38}$ Zia nevertheless co-opted pirs and congregations of pirs (mushaikhs) as he saw fit in order to bring them into conformity with his Islamization project. Zia's re-orientation thus led to attempts to fuse Sufism with (the ulama's) orthodoxy by claiming that the original Sufis themselves were mostly from ulama adhering to shari' $a$ whilst at the same time, or perhaps because of this, trying to lessen the role of the hereditary pirs. ${ }^{39} \mathrm{Zia}$ did however acknowledge the authority of the pirs, and sometimes included them in important conferences, such as the first convention of mushaikhs in August $1980,{ }^{40}$ and even promoted Sufi culture - something the following extract from a brochure published by Pakistan Tourism Development in 1985 suggests:

Muslim shrines and tombs of Sufi Saints represent Muslim culture [and] traditions. ... These Sufi Saints still rule over the hearts of Pakistanis and Muslims of other countries. With the passage of time

\footnotetext{
${ }^{36}$ Talbot (1999: 166).

${ }^{37}$ Rozehnal (2006) notes that the 'urs is often seen as a marriage with God - in the sense that it is with the death of a pir when he, or she, enters into the eternal union with God (p. 36).

${ }^{38}$ Aziz (2001: 56-7); Ewing (1983: 253-4, 263-4); Hassan (1987: 563).

${ }^{39}$ Ewing (1983: 254, 264); Qadeer (2007: 69). Ewing (1983) notes that in Zia's time, there was a concentrated effort to shift the focus from the pir being a holy man in his own right, to that of the pir being an alim; a (religious) scholar meant to educate and guide the followers in Islamic law (p. 267).

${ }^{40}$ Buehler (1997: 311).
} 
the number of devotees has increased. The visit to shrines by millions of people every year is an abiding testimony of their absolute and undisputed sway over their followers and of their divine blessings emanating from their hallowed graves. ${ }^{41}$

It is nevertheless reasonable to argue that Zia's moves were attempts at replacing the traditional system of piri-muridi with the orthodoxy represented through, at that time, Deobandi scholars and scriptural (Islamist) doctrine; which represented the backbone of Zia's Islamization process itself. Zia's Islamization did have an impact on how the institution of piri-muridi in Pakistan has changed. One major change was that religious movements, including that of the Sufis, became highly politicized, and in turn started preaching a more conservative version of Islam. During Zia's rule, mosques were increasingly designated and divided among sectarian lines, and subsequently connected to larger networks. This gave the ulama greater political and religious influence over them and in turn empowered local mullahs to challenge the institution of piri-muridi ${ }^{42}$ The orthodox seeds sown during Zia's rule have thus taken root and continue to influence popular opinion in favor of the orthodox at the cost of the traditional 'folk Islam' in Pakistan.

I now turn to discuss how orthodox Islam is challenging and influencing 'folk Islam' in urban centers, like the Twin Cities, in contemporary Pakistan.

\footnotetext{
${ }^{41}$ Cited from Buehler (1997: 299). Talbot notes that Zia did try to implement some policies that were seen as negative by the pirs. For instance, Zia challenged some of the sajjada nashins by implementing a ban on kite and pigeon flying, a practice associated with many Sufi saints, under the validation that they constituted a breach of sanctity and privacy for women. The authorities eventually had to withdraw the implementation of the ban (Talbot 1999: 251; Talbot 2004: 72). In contemporary Pakistan, kite flying is still a controversial theme, which is often banned by provincial governments.

${ }^{42}$ Abbas (2007: 16, 18).
} 


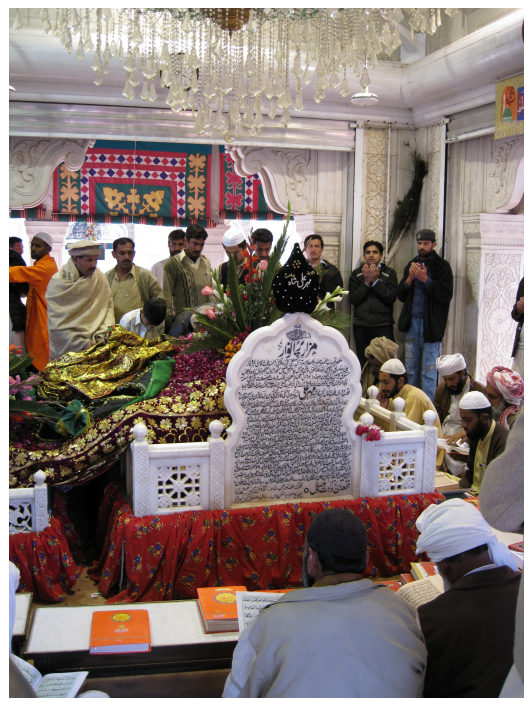

Figure 3. 'Urs at Golra Sharif, Islamabad.

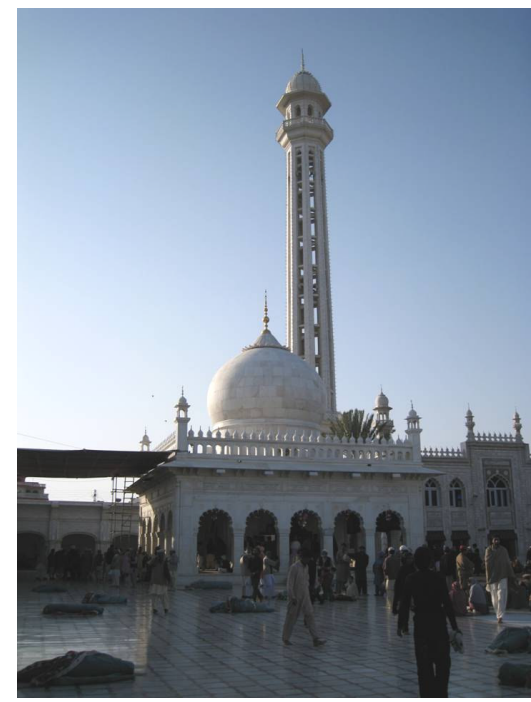

Figure 4. Golra Sharif, Islamabad.

\section{Orthodox Islam challenging traditional 'folk Islam' in the urban centers}

Contemporary urban Pakistan is witnessing a shift from the traditional system of piri-muridi, wherein the followers, the murids, would take the pir's, or the mullah's words for that sake, as 'the (only) truth'. People tend to be hesitant to reveal information regarding their affiliation with Sufism and seem hell-bent on trying to distance themselves from it - instead, rhetorically, portraying themselves as orthodox Muslims, who disregard anything seen as un-Islamic. ${ }^{43}$ In this context, Malik (2006: 31) notes that, “...a growing middle class of Muslim purists consider dance and music to be latter-day influences from non-Islamic sources, which have to be shunned." I am not limiting such a shift only to the 'middle class', rather, I find the phenomenon to be valid on a broader scale, including that of lower segments in the urban milieu as well. In this lies the fact that more

${ }^{43}$ Zaman (2004) argues that this shift from Sufi and shrine-based religiosity towards orthodoxy is attributed to the rise of sectarian organizations, and in turn, the Deobandi ulama's use of the sectarian environment (p. 136). 
people are turning to modern technology as well as utilizing traditional religious sources (Qur'an and Sunnah), which they access through a higher degree of availability to such sources amplified by increased education levels in general. This is something that Hassan (1987: 563), more than two decades ago, shared in his farsighted analysis, in which he argued that education and urbanization challenges the old 'folk Islam', weakening it and instead strengthening orthodox Islam. In his analysis, he argues that:

...the social change which Pakistan has undergone in the past three decades has created socioeconomic circumstances conducive to mass mobilization in support of a ulema-led purist Islamic tradition which I have elsewhere called Islamization. Urbanization, increasing literacy, and industrialization have created an urban environment which is sufficiently differentiated to provide the ulema and the purist Islamic tradition with an important and strategically located constituency. ...education and urbanization appear to be related to an increase in a universalistic religiosity and a decline in folk or popular Islamic practices.

In contemporary Pakistan, there is an increased emphasis on 'Islamic identity'; this is especially valid for the (educated) urban middle class. In the Twin Cities, this emphasis has led to a turn towards orthodox Islam at the cost of traditional 'folk Islam'. For example, the Wahhabi-oriented al-Huda movement is among the most popular movements for the urban middle class. In this, a new way of locating followers has developed. In previous times, the Tablighi Jama'at was the main organization known for going door-to-door in locating and recruiting supporters. In the last few years, other organizations, including al-Huda, Hizb ut-Tehrir, Jama'at ud-Da'wa, and Deobandi movements have begun to follow the same pattern as the Tablighi Jama'at, locating people in the affluent living areas of Islamabad, in shopping centers, as well as visiting people at mosques or in their homes. $^{44}$

\footnotetext{
${ }^{44}$ In this context, in an interview with the author, Amir Rana of Pakistan Institute for Peace Studies (PIPS) argues that the main reason for the middle class' attraction to sectarian identity is their awareness of local and international issues related to the post-9/11 situation. Rana adds that even the Hizb ut-Tehrir is popular among the middle classes in urban areas of Pakistan. Al-Huda does not portray themselves as a sectarian movement but still is related to a puritanical Wahhabi Islam - which more often than not condemns Barelvis in the way they pay homage to pirs etc. Al-Huda
} 
Deobandis, as seen earlier in this article, are often referred to as being orthodox and anti-Sufi. Still, many Deobandis have deep connections to Sufism but instead of entering into a 'blind relationship' with a pir, there seems to be a higher degree of intellectual reflection as well as a more personal and secretive approach in their Sufism. As I found in the study, quite often Deobandis would not reveal their adherence to it in public, nor alone when other people were present, but sometimes told me about their adherence to it in private. It is in this context I cite Roy (2002: 9), who notes that, "...the Deobandi do not oppose literature or poetry, nor even Sufism as such, although they condemn the "cult of the saints", i.e. addressing prayers to others than Allah." Indeed, it was among Deobandis that I was met with the most critical voices against saint worshipping, i.e. "cult of the saints", yet a certain few Deobandis also surprised me with their extensive knowledge of Sufism. Most often, these Deobandis would relate their responses to the intellectual aspect of Sufism, rather than practices and rituals commonly found at shrines (which they would most often object to). Still, I emphasize that these Deobandis were in a minority, as I agree with Rozehnal (2006: 44-5) who describes how the Deobandis in general have changed their attitude towards Sufism from having an intellectual closeness to it, towards rejection of it.

The orthodox movements' success in gaining supporters is starting to have an adverse effect on the traditional Barelvi organizations. The main reason for this is that the orthodox movements, such as al-Huda and Hizb ut-Tehrir, offer an alternative to the mystical, often secretive and difficult to understand Sufism as preached by the Barelvis. ${ }^{45}$ Furthermore, as Ayesha Siddiqa argues, "There has also been an exhaustion of the old, the traditional institution of piri-muridi". By this Siddiqa meant that they have stopped giving anything back to their followers. Thus, the missionary activities, the da'wa, of the orthodox movements seem to have a greater appeal to the (mainly educated) middle classes of urban centers as Islamabad. Concerning this, the director of Pak Institute for Peace Studies (PIPS) Amir Rana, says the following:

often preaches about universality of Islam and use words like 'equality', ummah, the brotherhood of Muslims, etc. in their rhetoric.

${ }^{45}$ Also see Qadeer (2007: 147, 153). 
I think right now the Barelvis are not paying attention - which comparatively with other sects here in Pakistan is [sic] more moderate in their religious ideology. They are losing ground, but they are also themselves responsible for losing this ground as they have very few religious practices in common which educated persons can believe in, e.g. what is going on in the shrine etc. This is also a response to the practices being done by the Barelvis, the pirs, and the scholars. Thus, people are inclined to go towards people who are more educated, they are appealing, they [the orthodox movements] can speak English, they are very well mannered; so in reaction they move to these movements.

The shift from the old 'folk Islam' may, as indicated earlier, be also probably related to increased access to newer technology such as Islamic TV broadcasts and the Internet. This is especially the case in Islamabad, where many of the residents are former emigrants to western as well as Arab states. In exploring this issue, I was initially very surprised to experience that former immigrants to countries of Europe and the USA - who, in the majority, had emigrated from traditional Barelvi areas such as Kharian, Gujarat, Lala Musa, Mirpur, etc. - were now applying Wahhabi rhetoric. ${ }^{46}$ Going deeper into this, I discovered that there had been a concentrated 'reinvention' of religion among many of these 're-emigrants'. In their re-discoveries, they had turned to technologies such as the Internet in locating 'the religion'. In many cases, their point of departure was said to be at a minimum: thus, when they started 'Googling' information on Islam, they mostly ended up finding orthodox Islamic websites.

These 're-emigrants' are often very engaged in supporting their local mosques, which often have their own religious seminaries (madrassas) attached to them, and donate large sums of money to these private institutions - something serving as one factor for the increase in orthodox, Wahhabi-based mosques in the capital in recent years. In practical and palpable terms, there exist multiple changes among this group. This is especially valid relating to marriage patterns (e.g. less focus on pre-Islamic rituals, instead turning to the 'pure' traditions in Islam), lifestyle (e.g. dressing more like Arabs; women's turn to the abaya and niqab, and men's wearing of Arab headscarves (rumal); leaving aside western dress codes), and discourse and

\footnotetext{
${ }^{46}$ Qadeer (2007) also finds that Pakistani workers in the Gulf and Arab states have brought back Islamic conservatism in their old settings (p. 269).
} 
rhetoric - which seem to be highly influenced by Wahhabism. ${ }^{47}$ This dimension to urban Islam has also been noticed by local academics, such as Professor Pervez Hoodbhoy at Quaid-e-Azam University in Islamabad, who told me in an interview that:

In a sense, this is natural because technology brings homogenization: you may now sit on the Internet and access Islamic web-sites globally. What does one see over there? The Qur'an and its translations, hadiths [collections of the Prophet's praxis, the Sunnah], fatwas, political commentary, etc. Those searching for Islam almost always arrive at a purer, more orthodox, view of the religion. This view is not tempered by culture, tradition, or historical experience. Instead, it is directly taken from the written word which is generally harsher than tradition, particularly that of Sufi Islam. Tradition had ameliorated some of the harshness that is inherent in the religion. In Pakistan, pristine Wahhabism is growing while the Sufi and Barelvi tradition is on the retreat. Slowly but surely one sees the pirs and 'folk Islam' become less important with time.

A factor in the increased shift towards orthodoxy at the cost of traditional 'folk Islam' is thus seen as being caused by increased levels in literacy and education in general. The argument is that when people have the opportunity to explore for themselves, they tend to read religious literature, including the authentic text of the Qur'an and the collections of hadiths. This is also the case for educational institutions outside the religious sphere, such as universities and colleges. Commenting on this, Hoodbhoy says:

Paradoxically, as literacy levels went up in Pakistan, the degree of orthodoxy also increased. Why? Because when people are able to read they read that which is available. Because religious books are all around and available at highly subsidized rates, people read largely about religious matters. A lot of literature comes from hard-line Islamic organizations, and this preaches a version of Islam that is pretty harsh.

On the other hand, shrines and pirs are most likely influenced by a growing orthodoxy in society as well. Not only are they reported to be preaching a more conservative version of Islam. This has in turn led certain shrines to implement a stronger discipline, like for instance an increased emphasis on reading of the Qur'an, as well as the banning of

${ }^{47}$ Qadeer (2007: 16) has similar findings in his work. 
women and discouraging of music in the shrine areas. ${ }^{48}$ Some, such as Abbas (2007: 16, 72), even point to the possibility that some pirs have ventured into the jihad game by sending the students of their madrassas as well as their murids to join the jihad against allied forces in Afghanistan. ${ }^{49}$

I now turn to look at how the people of the Twin Cities view the institution of piri-muridi and how they perceive certain practices and rituals commonly associated with it.

\section{Perceptions of piri-muridi}

In exploring issues related to piri-muridi in the Twin Cities, I had anticipated (and hoped for) many intellectual and/or spiritual reflections on what Sufism constitutes for the respondents. Alas, from the huge majority of people I interviewed, observed, and had conversations with, only fragments of such were found when they were describing their relations to Sufism. For some, it is a system of reciprocity, wherein one pays homage to the saint (pir) or descendent of a pir, being the good follower or disciple (murid) that one is supposed to be. For others, Sufism is something they have not fully thought through but still adhere to as they see that it can have some practical and religious benefits for them later. Indeed, as Pirani (2009: 36) argues, most murids, instead of 'investing in the spiritual training,' simply surrender to acts of obedience towards the pir. It is in this context that Robert Rozehnal (2006: 46), a contemporary scholar on Sufism in Pakistan, says that, "...questioning Pakistanis about their views on Sufism may elicit any number of responses-from reverent, extemporaneous recitations of the poetry of a local saint to harsh

\footnotetext{
${ }^{48}$ See also Gardner (1993) for a study of a Sufi-cult in northeast Bangladesh that has turned towards orthodoxy - banning singing and dancing, focusing more on recitation of the Qur'an and formal prayers (namaz), as well as limiting women's attendance at the shrine. Gardner attributes some of this change to the fact that many devotees are migrants (UK, Arab states) who have undergone orthodox transformations.

${ }^{49}$ Abbas (2007) introduces his readers to a 60-year-old respondent, who used to frequent shrines and had a formal relationship with a pir, having sworn his allegiance (bait/bay'a) to him, and later in his life emigrated to Saudi Arabia - where he became convinced that his previous practice of attending the shrines was shirk. The respondent later became involved in jihad in Afghanistan (p. 103).
} 
invectives against the moral depravity of the uneducated masses who flock to the shrines."

Very few people I met during the fieldwork explained pirimuridi in an intellectual context or by drawing on Sufi poetry or other spiritual explanations. I did, however, have the pleasure of being acquainted with a man who did offer such explanations: a local neighborhood 'living pir' (zinda pir) in his late seventies, originally hailing from Indian-administered Kashmir. The following is his explanation on how he entered into the world of piri-muridi:

It happened like this [how I became a pir]. Let's see, I sought my master [teacher, murshid] in my youth, and then I accepted his discipleship. At that time, I already had two small children. I went to Jalalpur to visit the murshid. Will he provide food for us or not (I wondered)? When I went to his shrine, my children had fallen asleep. I said to myself, "If he is a true pir, then he will provide us food; otherwise, I will not believe him." This is my own experience. This murshid of whom I became a disciple is now dead, now his son is his successor $\left[\right.$ mahant $;{ }^{50}$ the head of the shrine]. First time I visited the shrine, at one o'clock in the night, a number of people were sitting inside there. Then an order came from the inside, "Look for a person who has two children with him. First, food will be given to them and then distributed amongst others." People were looking for us in the mosque, here and there, but we were in the shrine. People were worried because they could not locate the person who they were told to feed. The mahant held a lantern and came inside shrine. I closed my eyes, when I saw him. He asked me to go with him to have some food. We were walking in front of him, and he was behind us with the lantern in his hands. He ordered someone to bring food and said that, "First your children will eat the food, then you will be served, and after that, other people will be served." I sought forgiveness and said that, "I wanted to test you; you have passed my test." That is the thing; at that time, truthfulness existed but nowadays it is gone. They [Sufis] were not liars. They worshipped Allah in the real sense.

Although the pir had stopped administering tawiz', and otherwise told people he was no longer 'in the business,' I regularly met people who said that they had received his help in various matters recently. $\mathrm{He}$ himself argued that he had stopped functioning as a pir as there were

\footnotetext{
${ }^{50}$ Note that the pir uses the word mahant, which is seldom used in contemporary Pakistan, as it is a Hindu word derived from Sanskrit and used to describe the head of a Hindu or Sikh temple.
} 
too many imposters, acting as pirs or faqirs, in addition to what he perceived to be an abuse of people's trust and money by most sajjada nashins. He also said that he believed he had become more 'scripturalist' (orthodox) during the last couple of decades, as he wanted to distinguish himself from what he called 'un-Muslim' (ghair Muslim) practices in contemporary piri-muridi. Perhaps because of this, I would regularly run into him in the local Deobandi mosque during prayers.

Before turning to what other respondents had to say about pirimuridi, another extract from the same interview with the pir follows, in which he explains one of his many strange encounters with Sufis of the past. In this story, the pir tells about an encounter he had with a man he believed was an imposter, selling tawiz' for money, only to be surprised that the man was not so and allegedly had special skills:

Once I saw a man who was clean-shaven, who smoked, and administered tawiz' to people for money. I told myself, "I will see what kind of a man he really is [whether he is an imposter]. I will check him out at night when he doesn't offer prayers." I made a hole in the wall and was surprised to see him. He was scattered in pieces! His legs, head, arms, and other parts of his body were scattered! And the voice 'Allah $h u$ ' [Allah is] came out from each part. I thought he was dead but the next morning I was amazed to see that he was still alive. I approached him and asked what had happened. He told me, "What you thought about me [imposter] was not right. There is a difference between my inner and outer self." Then he asked me not to disclose his secret during his life. Otherwise, I would have to bear damage.

From my previous informal conversations with people in Pakistan about piri-muridi, I had anticipated and hoped for more stories like the one in the extract above. Alas, most respondents kept their expressions of piri-muridi to practical and ritualistic aspects of it.

\section{'Sufism is an integral part of Islam, but some practices are un- Islamic'}

As seen from the table below, most respondents $(82.53 \%)^{51}$ perceive Sufism to be an integral part of Islam but among these, some $20 \%$

${ }^{51}$ When response options ' $a$ ' and ' $b$ ' are combined. 
added that the Sufism practiced in Pakistan has incorporated many Hindu and other pre-Islamic practices. These practices are not necessarily seen as legitimate (jaiz) practices per se, but rather as innovations (bid'at) derived from Hinduism or other pre-Islamic cultures and religions. ${ }^{52}$ For most people with whom I interacted in the Twin Cities, Sufism was neither intellectual nor seen as prescribed norms for how to live one's life. Rather, it was centered on the yearly functions of 'urs, keeping some sort of relationship with a pir, or occasional visits to pirs when in need of remedies and blessings. Those that argued that Sufism is the same as it was during early Islam mostly had no additional comments or information. When asked directly about specific issues, certain practices, or rituals, they would often say that they had no knowledge about the particular issue but feared it is inherited from the Hindus. Very often, respondents would ask how they were supposed to be knowledgeable about Sufism when they did not even have basic knowledge of Islam other than the rituals which have been passed on to them by their ancestors.

Table 1. Sufism as an integral part of Islam (Survey II).

\begin{tabular}{lrr}
\hline Do you consider Sufism (piri-muridi) as a part of Islam? & Total & Percentage \\
\hline a) Yes, everything about it is Islamic - as it was in the early & 297 & $62.53 \%$ \\
period of Islam. & & \\
b) Yes, but some practices are derived from Hinduism and & 95 & $20 \%$ \\
other pre-Islamic cultures. & 66 & $13.89 \%$ \\
c) No, it is not part of Islam. & 17 & $3.58 \%$ \\
d) Don't know/Refused to answer. & $\mathbf{4 7 5}$ & $\mathbf{1 0 0 \%}$ \\
\hline
\end{tabular}

Some respondents did explicitly express that Islam and Sufism in Pakistan consist of other cultural or so-called un-Islamic religiously inherited practices. For many of these, there were often expressions that these 'un-Islamic' practices should be gradually removed from

\footnotetext{
${ }^{52}$ Verkaaik (2007) notes that the ruling elite post-independence were instrumental in labeling Sufi practices, 'folk Islam', as impure (napak). This was especially valid for the relationship of the pir and disciple - piri-muridi (p. 90). Many non-Islamic, including Hindu customs and cultures were adopted by the early Sufis of the subcontinent (Aziz 2001: 7; Malik 2006: 30-1). Verkaaik (2005) also finds that some of the traditions relating to Sufism are commonly referred to as bid'at, innovations, by reform movements. At the same time, he still finds defense of the values found in the traditions in Sufism among his respondents (p. 48).
} 
the religion through enlightenment: religious (orthodox) education. Very few saw these culturally inherited practices and rituals as beneficial either for Islam nor for the people of Pakistan as such. Some few exceptions were found, however, such as the respondent quoted below, a 45-year-old retired Pakistan International Airlines (PIA) employee. His take on Sufism and Islam in general was quite atypical in the sense that he felt proud of having a religion that had assimilated different pre-Islamic values, rituals, and practices, which he did not see as 'un-Islamic', but rather as a proof of there being only one God. This is a short extract from this interview:

Sufism is a huge part of most people's lives in Pakistan, in fact in all of South Asia. In fact, Sufism probably has a greater role in people's lives than the real authentic [orthodox] Islam. This is a part of our legacy and culture; partially derived from Hinduism, Buddhism, and other religions.

The respondent furthermore pointed to another issue in the same interview: the place people hold for religion, in the sense that most people adhere to the 'easy way out', which for many is a form of Sufism, as opposed to the more intellectual and scriptural orthodox Islam (which the respondent refers to as authentic Islam). This aspect means that certain murids let their pirs perform their religious responsibilities on their behalf, for which of course, the pir is compensated. Although some will point to rituals and practices in pirimuridi as being 'un-Islamic', and thus argue that they should be removed or stopped, while going to the 'urs they very often seem to engage in and enjoy these 'un-Islamic' practices. Among the practices objected to I regularly found respondents condemning the tradition of getting into an ecstatic trance, a state of mind in order to achieve closeness to or even unity with God, often related to as dhammal. ${ }^{53}$

\footnotetext{
53 This dhammal is meant to achieve a state of ecstasy referred to as hal (conversations and interviews with Hugh van Skyhawk in 2007; Rozehnal 2006: 42). The hal is considered a state of ecstasy as a gift of mercy from God. In this state, humans are 'communicating with the ultimate reality.' Although the term dhammal is used to describe someone dancing, whirling, or other type of bodily movement in order to get into a trance with the objective of reaching unity with God, the actual meaning is the rhythmic sequence of drums, which is considered essential for inducing hal. It is also common for Sufis to turn to drugs, such as hashish and opium, and alcohol in order to reach hal. (Frembgen 2008: 167, 176, 183-8).
} 
Other things that are objected to are the practices of ritual offerings of salt (and other commodities), burning candles, gravesite rituals, and of course, the practice of some people at Sufi shrines of taking drugs or drinking alcohol. The following extract from an interview with a respondent, a 26-year-old part-time student, also uncovers another aspect to this dimension. The respondent highlights the fact that most entrances to shrines are relatively low in height, hence one has to bend down, to bow before the pir (which is common when meeting them in person), which he perceives as being unIslamic:

Yes, it is [part of Islam] but we have to think and reassess some of the things going on. The sajjada nashins should tell the murids about the original Sufis, about their life routine, their prayers, and their living style and should ask them to do the same. It should not be like going to the graves once in a year [for the 'urs], putting a piece of cloth on the grave [chadar] and acting 'dhammals' together with women and that's it. These things should be avoided because these are un-Islamic. .... a lot of things [are derived from Hinduism], for example, the door of a mosque is usually high but in shrines they are short in height and people have to go through them by bending down. The same is the case of the temples. Then you see people offering salt, burning candles, etc., which also is in Hinduism. I think it is not a part of our religion. Burning fire and after that acting 'dhammal' and dancing. ....all these things that they do are not in our religion.

Yet, despite these so-called un-Islamic practices in piri-muridi, as practiced at shrines, many people do go there. However, as I will explain in the following, even more people might indeed go to functions at shrines or otherwise visit pirs, but as they are embarrassed to reveal their affection for it, they often decline to admit it. 


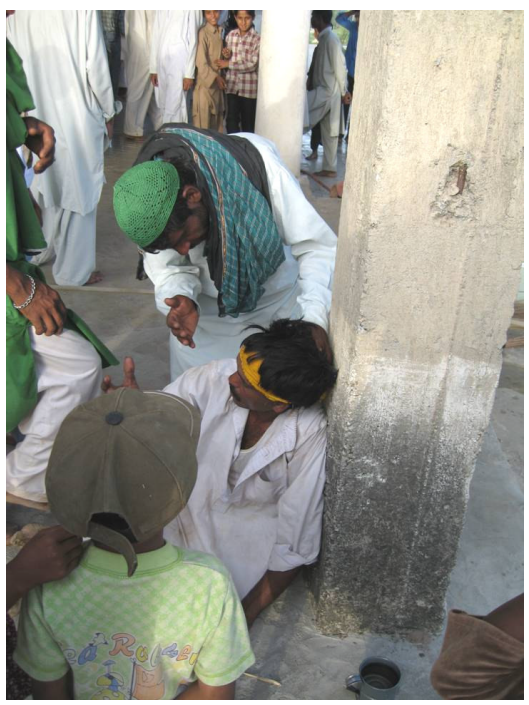

Figure 5. Murid after dhammal.

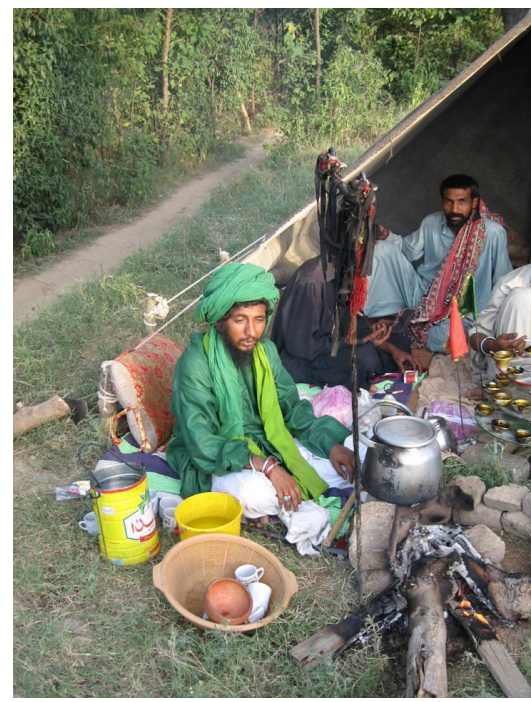

Figure 6. 'Sampling the products.'

\section{'Of course I go there, but it has changed its character'}

As seen from the table below, I found the number of respondents saying that they go to Sufi shrines or visit the yearly 'urs of pirs $(31.37 \%)$ much less than the number of respondents who said that they perceived Sufism to fully be part of Islam or with some preIslamic rituals integrated in it (which totaled $82.53 \%$ ). ${ }^{54}$ This figure is probably higher in practical terms, as I have found that many people do not even tell their relatives that they visit shrines or otherwise seek help from pirs. Thus, I would instead see the figure presented as those 'admitting to going to shrines or visiting the yearly 'urs of pirs'. The main argument for this is that many respondents seem to be embarrassed at disclosing their relationships with the shrines.

\footnotetext{
${ }^{54}$ A Gallup Pakistan survey, titled Views on Visiting the Graves of Famous Saints, January 2010, finds that $52 \%$ of Pakistanis admit to having visited shrines of pirs, $47 \%$ said they had not. I see the discrepancy between Gallup Pakistan's findings and my own to be caused by two factors. Firstly, Gallup Pakistan asked whether respondents had visited shrines, whereas I asked if respondents visit shrines. Secondly, and perhaps most important, Gallup Pakistan's survey includes rural and urban respondents alike; rural respondents are more likely to having visited shrines than their urban counterparts.
} 
Respondents sometimes express that they feel that although it provides comfort to them, piri-muridi is argued by 'most people' to be something ancient and an institution that only 'eats out of the poor man's pockets,' taking advantage of them - a point that I will return to below.

Table 2. Visiting of shrines and attendance at 'urs of pirs (Survey I).

\begin{tabular}{lrr}
\hline $\begin{array}{l}\text { Do you ever go to Sufi shrines or visit the yearly 'urs of } \\
\text { pirs? }\end{array}$ & Total & Percentage \\
\hline a) Yes. & 149 & $31.37 \%$ \\
b) No. & 308 & $64.84 \%$ \\
c) Don't know/Refused to answer. & 18 & $3.79 \%$ \\
& $\mathbf{4 7 5}$ & $\mathbf{1 0 0 \%}$ \\
\hline
\end{tabular}

For those who admit to going to the shrines, this admission is very often followed up by clarifications in the sense that they only go there to pay their respect to one particular pir or simply to offer funeral prayers (fateha) ${ }^{55}$ I often found the tendency among respondents to emphasize their disapproval of some of the practices and rituals taking place at the 'urs. This was most evident when respondents described people who consume drugs and alcohol, dance, or engage in other socalled 'un-Islamic' activities at the shrines. Respondents would often add that the 'urs had suffered due to cynical people trying to gain material wealth for themselves, for instance by selling artifacts, prayer books, and other 'glossy items' such as decoration pieces for homes and cars etc., which are common in the marketplaces (melas) set up adjacent to most larger shrines. Another important issue, echoed by most respondents was a negativity towards going to the shrines in order to beg for something for themselves, either from the sajjada nashins or through the shrine itself. Instead, most respondents would argue that they were only paying their respects to the deceased pirs by offering fateha prayers. Some, like the following cited respondents, a 35-year-old man working as a shopkeeper and a 27-year-old owner of a Public Call Office (PCO), would express that people have lost the

\footnotetext{
${ }^{55}$ A Gallup Pakistan survey, titled Views on Visiting the Graves of Famous Saints, January 2010 , finds that $64 \%$ of Pakistanis admitting to having visited shrines of pirs said they went there to show respect, $34 \%$ said they visited to get their prayers fulfilled or wishes come true, $11 \%$ said that they went there to receive spiritual healing, $4 \%$ said they visited shrines to receive free food or gave no response.
} 
'true meaning' of going to the 'urs. The main argument was often that in the past people would go there to learn about the old Sufis' ways and then try to follow their examples in their own lives. The respondents say the following:

Shopkeeper: Of course I go there! They [pirs] are the beloved people of God. They used to spread Islam. Now look at us, what we are doing today. We go there and abuse their shrines; people go there and become intoxicated; drink, use drugs, and people are beating the drums and dance over there. That is a total abuse of the dignity of the shrines. I don't say that people should refrain going there but they should (go there to) recite the holy Qur'an, offer fateha prayers, and beg from God. A special prayer from God in order to make us like these people [the original saints, pirs], and make us like the people who followed [murids] these saints [in the past]: these things are correct.

PCO owner: They $[$ pirs $]$ are on the right path. They sacrifice their lives, families, and properties just to earn Allah's favor. Whatever they begged for, they achieved from Allah. Certainly, we must go their shrines but not beg something from these graves, and not burn candles etc. These practices are prohibited in Islam. I have been visiting Bari Imam [shrine in Islamabad] and many other renowned places. All these evils ['un-Islamic practices'] have been adopted because of some of the people going there.

Also, consider the following from another respondent, a 27-year-old businessman commuting between Pakistan and Saudi Arabia, arguing that although on the one hand it is acceptable to visit shrines, on the other it is heresy to maintain gravesites for longer periods of time. He said that he was basing his perceptions on his long stays in Saudi Arabia, where his experience with gravesite practices was obviously different. ${ }^{56}$ On this issue, the respondent says:

I usually go to 'urs at different shrines, but I don't have that much interest. We only go to give grace to and worship some special pirs. Some of the practices in Sufism are actually Hindu, and I don't like that. For instance, when we bury people, people make a huge fuss about it: burning candles, decorating, setting up stones etc. That is not in accordance with Islam. In Saudi Arabia, people are buried, and

\footnotetext{
${ }^{56}$ Abbas (2007) has similar findings in his work. He attributes the 'sinfulness' of going to graves to Wahhabi influence brought home by emigrants to the Middle East (p. 60).
} 
after ten years or so, the graves are cleared, in order to create space for new ones. We should not be making large graves, putting up stones etc. Again, this is the work of the religious leaders; they want to be remembered, so they make it happen. In addition, many people are exploiting the situation, taking drugs and alcohol, saying they want to experience 'the oneness' [tawhid] of Allah, while in fact they are only bad people [haramis]. But we [can also be understood as I, from ham] still go there; it is our habit ['adat].

As seen in the extract above, the respondent claims that the main problem with the shrines is that religious leaders themselves encourage the system as a way of being remembered and worshipped after their deaths, thus also sustaining the family heritage and securing income for generations to come. Still, as he himself admits, he goes to the shrines and attends 'urs, saying that it is related to his (family's) customs and traditions.

Whereas contemporary mainstream Pakistan is highly sectarian, the shrines bring together a myriad of sects, sub-sects, and religions. Not only are the shrines popular places of worship for Sunnis: Shias, Hindus, and even Christians alike visit them regularly, especially for the "urs ceremonies. ${ }^{57}$ What I initially found odd was that many Christians would say they that would regularly visit shrines of pirs and go to 'urs. While talking with them, most said they go there because they have faith (iman) and that the chain (silsila) of pirs has been part of their upbringing. ${ }^{58}$ In this context, they often downplayed the differences between themselves as Christians and the majority Muslims in society, often arguing that there was very little separating them in practical terms and social transactions in society as a whole. Returning to the practice of going to the shrines, some of the Christians maintained that the major reason for going there is related to an old practice of the pilgrimage to the Shrine of Mariyam, which is specifically known to be a place where childless women go to get

\footnotetext{
${ }^{57}$ Fieldwork notes; Mohammad (2002: 229). Qadeer (2007) in his findings also report that sectarian differences matter little at shrines (p. 74, 256). Van der Veer (1992) in his research on Sufism in (Indian) Gujarat, found that Hindus were present and even participated in some rituals at some shrines (p. 555, 562). Frembgen (2008) also notes that Hindus venerate Muslim saints, although as he notes, "The latter [Hindus] see the saint, who is considered to be alive (zinda), as an incarnation of god Lakhsmana, in myths the son of Vishnu and the brother of Rama." (p. 26, 35).

${ }^{58}$ Silsila in this context is the chain of connection between the pir and the murid; an order (See for instance Kazimi 2009: 35 for further details on this concept).
} 
blessings in order to become pregnant. In this context, most Christians would mention that even Muslims go to this particular shrine to get blessings.

As seen from the table below, those respondents who said that they did not visit shrines expressed that they did not care or believe in the institution as such. When talking to them in greater detail, however, the common explanation was that they would like to go but seldom found the time to do so. Thus, arguably, more people would visit the shrines if they found the time.

Table 3. Reason given for not visiting shrines/attending 'urs (Survey I).

\begin{tabular}{lrr}
\hline If you do not go to Sufi shrines or 'urs, why not? & Total & Percentage \\
\hline & Of total respondents & \\
a) I don't think it is permissible in Islam. & 50 & $10.53 \%$ \\
b) I don't care/believe in such things. & 199 & $41.89 \%$ \\
c) Don't know/Refused to answer. & 59 & $12.42 \%$ \\
& $\mathbf{3 0 8}$ & $\mathbf{6 4 . 8 4 \%}$ \\
\hline
\end{tabular}

\section{'They have lost their way'}

I found most respondents to adhere to the idea of pirs having some kind of power to intercede on their behalf in earthly matters. These earthly matters would range from (blessings for) having children, receiving cures for medical or psychological illnesses, being promoted or getting married, to resolving economic misfortunes. My observation regarding this is that people in the Twin Cities will visit their (hereditary) pir, usually after a qawwali session, after the 'urs, or whenever the pir is available for the public, and then offer their 'silent wishes'. Then, the pir 'intercedes' with God on their behalf. Mostly, this intercession is conducted through advice which is often given to the murids in philosophical and/or complex language, or, as is very common, the pir prescribes a practical cure. The practical cure is achieved either by blessing an item or (holy) water (ab-e-zam zam) brought by the murid, advising the murid to say special prayers ( $\left.d u^{\prime} a\right)$, and/or giving the murid an amulet or a pendant (tawiz) said to give relief or comfort. 


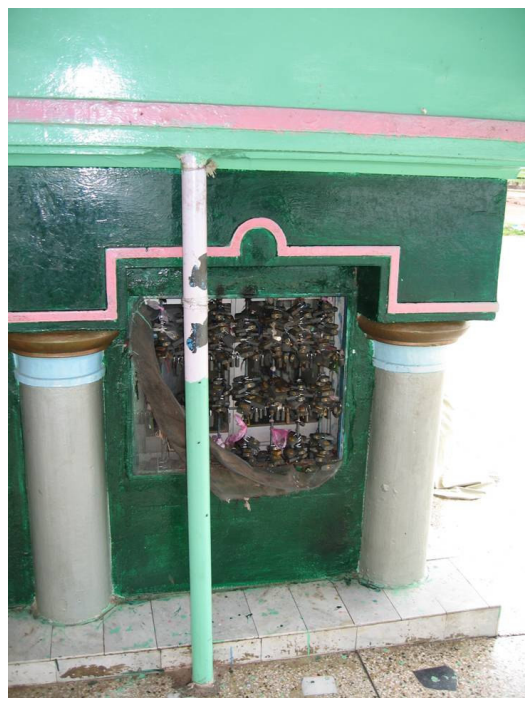

Figure 7. 'Locked-prayers'.

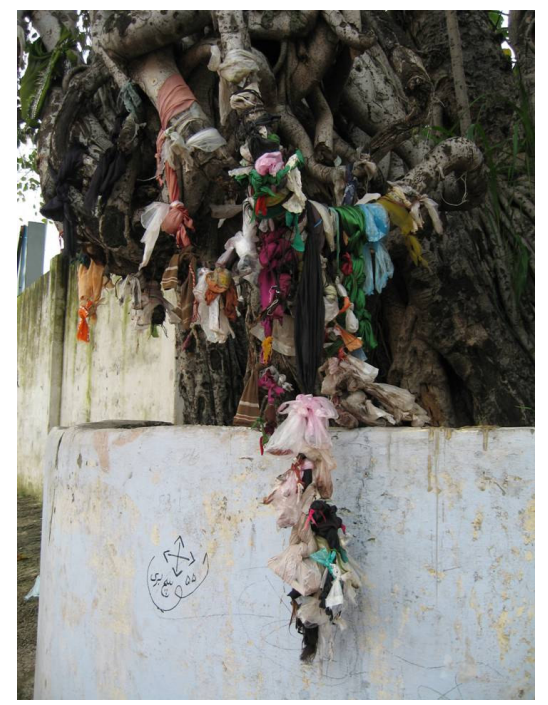

Figure 8. 'Prayers in a tree'.

The tawiz usually consist of either a simple (mostly black) thread or a combination of a thread and a small piece of paper with certain verses or extracts of Qur'anic verses written on them. In addition, there is often written a series of three-digit letters - which the pir claims have some specific meaning, although this is not revealed to the murid - to help them gain their wishes. The tawiz will normally be put in a locket or sewn inside a leather cover and worn around the neck or on one of the arms. There also exist other types of tawiz'. For instance, some are hung in trees (these are usually pieces of cloth that are hung in trees adjacent to the shrine) or put on (the exhaust pipes of) automobiles, and some even are made to be rapidly thrown and dissolved into water or fire, which again is said to rapidly trigger the desired effect. It is sometimes maintained that once the murid's wish has been granted, the tawiz will automatically disperse, although I have often witnessed people coming back to the shrines in order to remove their (hanging) tawiz after their wishes have been granted.

The wearing of tawiz is contested among some. It is often perceived as an act of idolatry or polytheism (shirk), although I found most respondents, including Deobandis, to permit the wearing of tawiz 
for one's safety: so-called hifazati tawiz. ${ }^{59}$ For such an example, see the following extract from an interview with a 36-year-old (Deobandi) respondent currently working as a taxi driver:

It [tawiz] is according to Islam. It is also useful for bad sight. [In addition to the pirs] it is also administered by the ulama but they do not play with people as some false pirs do. My child has one around his neck because he is frightened at night and starts sleepwalking in the house. Angels are also with my daughter, who studies [at Lal Masjid] in Islamabad, she also wears it around her neck. Tawiz is legal in Islam.

As pointed out by the respondent, even some among the ulama administer tawiz'. I only came across a few people who had had been administered tawiz' from the ulama, and based on these few, it seems that the tawiz' given by members of the ulama are not particularly mystical or difficult to understand, but instead consist of special Qur'anic verses believed to relieve people of discomfort or illness. I also found certain Deobandis who had been advised by religious leaders to wear (silver) rings or pendants with semi-precious stones such as turquoise (firoza) or carnelian (haqiq) attached to them, as these stones are said to have healing or comforting powers. The wearing of such rings is also very common among Barelvis. Usually the pir will receive money or another type of gift (futuh) in return for his services. After an interceding session with the pir, which usually involves the murid bending down before the pir, most often the murid donates an amount of money to the pir - which is given as a gift to the shrine. In this process, the murid declares or reassures his allegiance

\footnotetext{
${ }^{59}$ Pirani (2009) notes that faith healers prescribe a variety of treatment including amulets, holy water, special prayers $\left(d u^{\prime} a\right)$, and slaughtering of animals in dealing with health conditions (p. 66). I found it common to believe that pirs had to power to intercede, or to call upon people to become murids for instance, through dreams. Very little substance came out of the conversations I had with people on the issue, most saying they were too embarrassed to disclose any information at all, albeit they strongly believed that pirs regularly visited people in their sleep (fieldwork notes; also see Ewing (1990) for more on pirs interceding with people through dreams). Abbas (2007) mentions one example of a young Barelvi whose mother, after he changed his daily religious rituals towards Wahhabi practices, brought him to a pir in order for him to see the mistake he had committed. The pir gave the man a tawiz to be put under his bed in order for him to be 'put on the right track' (p. 41). Frembgen (2008) also provides some accounts on the pirs' practice of writing and administering tawiz to murids (p. 32).
} 
to the pir by kissing his hand (or ring on his finger). This process of swearing allegiance to the pir is often related to as bait/bay'a.

Table 4. Whether visits to shrines will enhance one's life (Survey II).

\begin{tabular}{lrr}
\hline $\begin{array}{l}\text { Do you think that going to pirs, 'urs, or other Sufi } \\
\text { gatherings will enhance your life? }\end{array}$ & Total & Percentage \\
\hline a) Yes, these people have real powers. & 356 & $74.95 \%$ \\
b) No, they are just frauds/imposters. & 97 & $20.42 \%$ \\
c) Don't know/Refused to answer. & 22 & $4.63 \%$ \\
& $\mathbf{4 7 5}$ & $\mathbf{1 0 0 \%}$ \\
\hline
\end{tabular}

Some respondents believe that pirs have 'lost their way' in the sense that they are taking advantage of the 'common man' without putting anything back into the system (i.e. providing for the people). On this issue, there are ambivalent views: on the one hand people believe pirs have the power to intercede before God, and on the other, do not feel that it is appropriate to beg for anything from anyone else than God although by having the pirs intercede on their behalf, they do so in practical terms. This point is also related to the next issue, in which there also lies some ambivalence. Most respondents will say that pirs are taking advantage of 'the common man' by defrauding them of what little wealth they do possess. As seen from the table below, this figure is relatively high, almost $70 \%$. In addition, the respondents answering 'Don't know' often said that they suspected that pirs were taking advantage of them but had no way to confirm it and did not want to challenge the pirs in as they saw a potential future danger in upsetting them.

Table 5. Pirs taking advantage of 'the common man' (Survey I).

\begin{tabular}{lrr}
\hline $\begin{array}{l}\text { Do you believe Sufi pirs are taking advantage of 'the } \\
\text { common man'? }\end{array}$ & Total & Percentage \\
\hline a) Yes. & 331 & $69.68 \%$ \\
b) No. & 76 & $16 \%$ \\
c) Don't know/Refused to answer. & 68 & $14.32 \%$ \\
& $\mathbf{4 7 5}$ & $\mathbf{1 0 0 \%}$ \\
\hline
\end{tabular}

The ambivalence with which the murids offer their respect, and often money or other items, to the pir on the one hand, and at the same time say that they are probably being taken advantage of, seems illogical 
on the surface. This system is probably partly linked to old notions of reciprocity. This system of reciprocity between the pir and the murid - hence the name piri-muridi - is a system wherein the murid is supposed to keep the chain (silsila) of his or her ancestors intact. In this, the murid is expected to keep up the tradition of obeying his or her specific (hereditary) pir, although the murid might have started to question the validity of the institution of piri-muridi as such. One respondent, the same 45-year-old retired PIA-employee referred to earlier, after saying that he regularly visits shrines and attends 'urs, as well as having an active relationship with a pir, said the following about the practice of certain pirs of taking advantage of people:

Certain people are taking huge advantages of this [piri-murid]; selling prayers, tawiz', and other blessings etc. They are professionals, thieves, just taking advantage of the [unfortunate] people; the followers (murids). The pirs still dominate society; they keep large support bases, which they even mobilize in elections etc.

The respondent also pointed to another important factor; namely that of the pirs' involvement in politics. This aspect will be discussed later in this article.

In addition to the aspect of pirs taking advantage of people's faith by 'stealing their wealth,' there also exist reports of physical and mental abuse going on at some shrines. ${ }^{60}$ In the general context of pirs taking advantage of people, there is a common perception that the 'real pirs, faqirs, dervishes, and Sufis,' representing the true and authentic powers, have gone into hiding, or rather into a state of occultation. The 'visible pirs' and the shrines they maintain, in the function of being sajjada nashins, are thus seen as not possessing the real powers that the 'hidden pirs' possess. The reason why the 'real pirs' have gone into hiding is regularly explained as being a consequence of society's downfall, which has opened the path for bad people, allowing some of the sajjada nashins, to turn the old shrines and the institution of the shrines, into 'money-making' factories for themselves without giving anything back to the people. See the following excerpt from an interview with a respondent, a 28-year-old shopkeeper, who feels this way:

\footnotetext{
${ }^{60}$ See for instance Pirani (2009: 73). Pirani found that a small group of people was being held at a shrine against their will. In those cases, parents or other elders had made the decision to keep them there (p. 272).
} 
All these people, the pirs, they are just number twos [do number pir; imposters]. In the past, there used to be good pirs as well, they are now all gone; they have gone into hiding. Just look at the people in Golra [Sharif] they are only interested in politics and money, and in Pakistan if you are involved in politics, you get the money. They are only giving back a little, you can go and eat at their langars [langar khana], and stay there for some days, but it is nothing like it used to be. I don't have the exact knowledge [of how it used to be in the past], but people say it was very different before. The pirs used to have powers, help people etc. They have lost their way. They are the ones that should help the people, but now the people are the ones providing support for them, and they [pirs] enjoy it very much. Look at their big buildings, dazzling cars - it is not right.

The following respondent, a 25-year-old currently unemployed man who volunteered at a local (Deobandi) madrassa, also expressed a similar view. He emphasized the important role of pirs and individual Sufis in previous times, and argued that this role is now filled by movements such as the Tablighi Jama' at, as the 'true pirs' have gone into 'hiding':

After the Prophet and his companions, pious people [pirs and Sufis] became the cause of spreading of Islam: people such as Ali Hajweri in Lahore. Now this work is being done by Tablighi Jama'at, especially in Raiwand [Tablighi Jama'at headquarters in Pakistan], where thousands of people are always involved in preaching/missionary work $\left(d a^{\prime} w a\right)$ and teaching. Groups are being sent to the whole world for preaching. Non-Muslims are rapidly converting to Islam. I think it is the righteous way as they spend their own money, lives and precious time... Nowadays, true pirs, in its true sense, are very few. Because of these no-good pirs they [the true pirs] are now hidden.

The respondent points to an important factor when he mentions the Tablighi Jama'at; as mentioned earlier in this article, orthodox movements, such as Tablighi Jama'at are challenging the traditional 'folk Islam'. Not only are they 'giving something back' to the people through their charity work, they also treat people with respect, for instance by relating to them as brothers (bhai) and otherwise addressing and conversing with them in a respectful manner. This behavior is quite opposite to the practice commonly found at shrines, where it is the norm that one bows before the pir and treats him like a monarch. 
In the context of 'pirs having lost their way,' Ayesha Siddiqa Agha, herself having filled the role of a pir, acting as a female pir (sheikha) after her father died when she was in her early teens, draws on her own experiences and elaborates on this issue. Siddiqa explains that the practice of certain pirs and the institution as a whole to just 'take' from the murids without giving anything back, might also be related to the higher popularity of the orthodox movements. In the past, this type of reciprocity functioned in the sense that the pirs would help their murids and give them time and attention. In contemporary Pakistan, attention increasingly comes from the orthodox movements, which also tend to treat their subjects as equals, thus breaking old patterns of higher and lesser status between the religious/spiritual leaders and their murids. Siddiqa says the following about the lack of giving anything back to the people (murids) and hints at the consequence this might have in the future:

These people [pirs] are accessible, but again, putting very little into the system, e.g. there are at least 14-15 members of my family - I don't do it - who constantly go on safar [travels, collection of nazar], visits to the murids, and the murids are spread from Sindh to Baluchistan. They go there, visit them, bless them, get money - so every time they run out of money they go on a safar. Any young boy in the family who is pathetic, can't do anything with his life and has no independent source of income, goes for safar. That's the method of sustenance: that is what I call spiritual predation. The problem with predation is, as the word explains, that it does not give anything, it just takes, it exploits. On the other hand you have, it is not an issue of challenging their philosophy, Akora Khattak [Haqqania Madrassa] and others, but they are at least giving the sense to the people that at some point they can be equal.

It has to be emphasized that although some sajjada nashins might deliberately take advantage of their murids, people do go there (mostly) on a voluntary basis, in that sense that they are 'letting themselves be taken advantage of.' In this, I regularly found attendees at shrines to have traveled long distances, even from abroad, to attend an 'urs or otherwise to meet the pir. When asked about whether they thought they were being exploited, many quickly replied that they were not so, and that they gave away money on a voluntary basis because the pir had played a role in their ancestors' prosperity or the curing of disease, or just that they felt that they were being cared for 
by the pir. Most shrines also offer their murids food through their langar khanas, medical services, as well as other practical assistance and advice, which I often found to be cherished by the attendees.

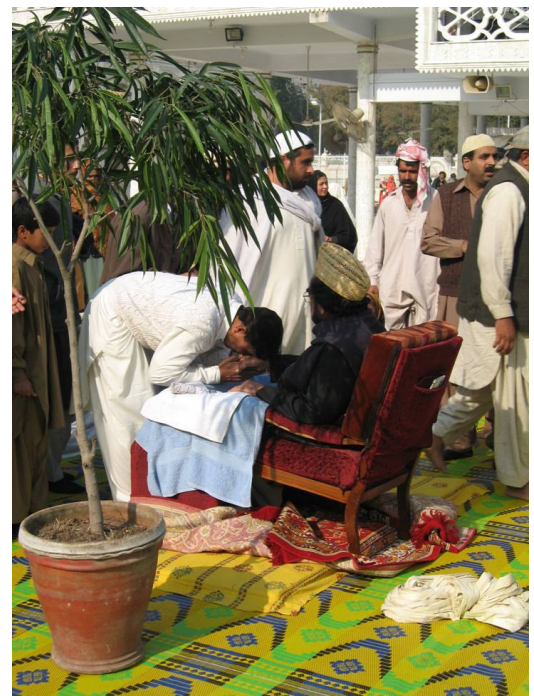

Figure 9. Paying allegiance (and money) to the pir.

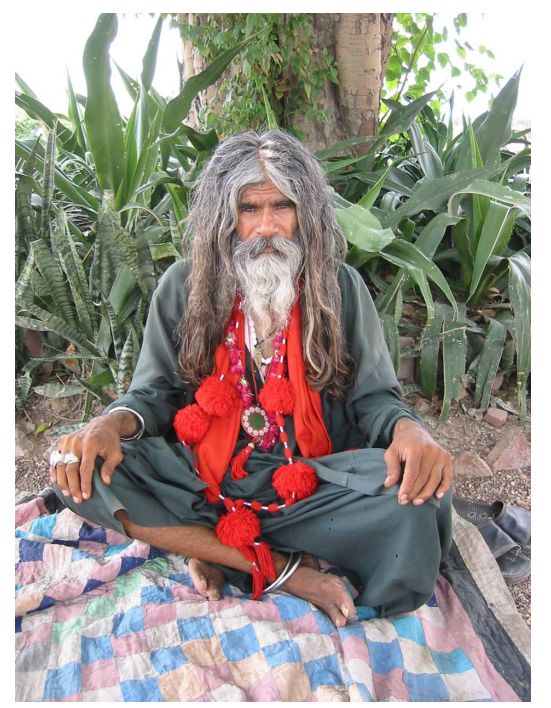

Figure 10. Dervish in the outskirts of Lahore.

\section{'It is OK to go there to offer fateha, but not to ask for something for one's self'}

The visiting of graves is considered desirable or commendable in (most schools of thought in) Pakistan's Islam, as it is thought to serve the function of reminding men that death is certain and that men are mortal. It is also a way of seeking forgiveness from God for one's own sins. By Qur'anic tradition, visiting gravesites is said to be for men only. Thus, the practice of the many female murids going to shrines is considered haram by Deobandis and Wahhabis. In most cases, respondents will say that they go to the shrines primarily to offer prayers for the deceased, the so-called fateh a prayers, where the sura-e-fateha from the Qur'an is recited. ${ }^{61}$

\footnotetext{
${ }^{61}$ There are also those that resist the idea of going inside a graveyard altogether. Abbas (2007) finds an example of this in his work (p. 60).
} 
Table 6. Permissibility in going to the shrines for fateha (Survey II).

\begin{tabular}{lrr}
\hline Is it OK to go to a Sufi shrine for fateha? & Total & Percentage \\
\hline a) Yes. & 451 & $94.95 \%$ \\
b) No. & 13 & $2.74 \%$ \\
c) Don't know/Refused to answer. & 11 & $2.32 \%$ \\
& $\mathbf{4 7 5}$ & $\mathbf{1 0 0 \%}$ \\
\hline
\end{tabular}

At the shrines, many murids offer personal prayers $\left(d u^{\prime} a\right)$ meant for God alone, although many respondents address their $d u$ 'as to the shrine (or its deceased pir). This practice is seen by many respondents as an act of shirk, as prayers should only be offered to the one God. At shrines, it is also considered common practice to for instance burn incense (agar batti), heat special oils (charagh), decorate the graves, lay down rose-petals, and pour rose-scented water over the shrines. These practices are seen by many, especially among Deobandis and Wahhabis, as idolizing the dead and conducting these practices on graves or shrines, with the exception of the holy Ka'aba in Mecca, are often explained to be shirk, as it is seen as ways of challenging the concept of worshipping the only (one) God. As this respondent, the same 27-year-old owner of a PCO referred to earlier, argues:

We should go to pray [fateha] for those who are buried. We must not, however, beg anything from them because it is forbidden in Islam to bow before anyone other than Allah. If it were so, wives would bow before their husbands. Thus, one should not bow before pirs or go to them for one's own needs. Still, you can observe that these things happen if you visit shrines.

Peter van der Veer (1992: 557) finds similar tendencies in his research in a Sufi environment in Indian Gujarat. Concerning the practice of going to the shrines, he refers to Deobandis of the Tablighi Jama'at, who are regularly seen as orthodox and opponents of 'folk Islam', and writes that:

Muslims in Surat and its twin city Rander who call themselves Tablighi do not participate in or observe a saint's day ['urs]. The Tablighi Jamat is sometimes called an anti-Sufi movement, but according to the Tablighis I interviewed this is a misrepresentation. They do not oppose Muslims visiting Sufi shrines (dargah), but are against prayers to dead saints to intercede with Allah on behalf of the supplicant. The Tablighis cite the standard reformist argument that to 
worship a saint in addition to Allah amounts to polytheism (shirk). In their view, a good Muslim should demand nothing from the buried saint or from his living descendant, but they do not object to visits to the shrine to pray for the benefit for the dead. The Tablighis present, then, an inversion of the usual Sufi practice in which the believer prays for his own benefit to the dead saint.

Van der Veer's (1992) findings concerning certain practices of 'folk Islam' being assessed as acts of shirk, as seen from the paragraphs above, are very similar to my own findings.

The tradition of asking something for one's own needs is common practice when visiting shrines of pirs, although this is not necessarily admitted by respondents, as seen from the table below.

Table 7. Permissibility of going to the shrines for one's own needs (Survey II).

\begin{tabular}{lrr}
\hline $\begin{array}{l}\text { Is it OK to go to a Sufi shrine in order to beg for something } \\
\text { for one's self? }\end{array}$ & Total & Percentage \\
\hline a) Yes, pirs have been given power by God in order to help & 14 & $2.95 \%$ \\
people on the earth. & & \\
b) No, one should only beg to God. & 451 & $94.95 \%$ \\
c) Don't know/Refused to answer. & $\mathbf{4 7 5}$ & $\mathbf{1 0 0 \%}$ \\
\hline
\end{tabular}

Many people offer their prayers ( $\left.d u^{\prime} a s\right)$ directly to the pir or shrine, try to 'gain from the baraka' of the shrine, or receive healing at the shrine. Many people will place small padlocks or threads on the bars of the windows or the metal grills located inside the shrine, hang pieces of cloth with their $d u$ 'as wrapped inside on the trees adjacent to the shrine, or otherwise bring something to be kept at the shrine or its surroundings, to be removed when their wishes are fulfilled. ${ }^{62}$ As part of the ritual when entering the shrine, one will experience people bending down over the tomb, touching it, and then fanning their hands to their faces repeatedly to get some of this baraka, in order to obtain

\footnotetext{
${ }^{62}$ Pirani (2009) notes that some of the respondents in her research tied threads or chains around the doors of the shrine or around trees in the surrounding. She was told that these items served as witnesses to the requests that were made to the saint and served as some kind of protection for the murids. She also discovered that the murids believed that in their absence, the items would remind the saint of their request - so that it would be granted and that, when it became granted, it would 'fall off' (p. 197$8)$.
} 
blessings or cures for illnesses. Some even bring items, such as clothing or (holy) water inside the shrine, as if to bless them. ${ }^{63}$

On certain occasions, I would also witness people carrying large chains around their bodies; they would always reply that, "They were in God's custody." When asking more about this - whether it was a punishment of some sorts, for instance - the usual reply was that it was a commandment of Allah, and not by the order of any pir. These people referred themselves as faqirs, although they were not the only ones calling themselves that. ${ }^{64}$

Using common rhetoric on the issue of the illegitimacy of 'begging for one's self', a respondent, the same 36-year-old uneducated taxi driver referred to earlier, expressed his view on this in the following:

They [dead pirs] have no powers. They are dependent upon us because they are dead and we are alive. We buried them in graves and put lots of soil on top of that. They are our dependents because they are dependent on our fateha and [du'a-e-] darud. When you enter a graveyard, you do not know what is going on inside the grave. When you go there and pay your greetings [salaam], they reply but we never know. I have never gone inside a tomb [mazar] but I have prayed for them from the outside. Some people who regularly go there and say that they have prayed for me. Their prayers have been successful; I became rich, I had a child. Allah does not like those people who seek help from others. Allah listens to all prayers and replies, but some

\footnotetext{
${ }^{63}$ Pirani (2009) finds some of the same behavior in her research. In addition, she notes that some would bring home the leftover, diluted oil from lanterns standing around the shrine to be used as massage-oil. This oil could also be bought at stores surrounding the shrine - in this lies, she argues, that the devotees could bring a piece of the shrine of with them as a reminder of the shrine and the saint (p. 191-2). I have also noticed oils, and other things found in the shrines being sold at the local melas (especially for Golra Sharif and Bari Imam where melas make up a huge part of the shrines' surroundings. What I however found, was that the murids would take these items to the hereditary pir in order to have them blessed and then taken home or sacrificed. In this, I also found murids bringing salt from home, which they would place into large bowls of offering inside the shrines - this is more noticeable at certain smaller shrines, and could be limited to Shia practices.

${ }^{64}$ Pirani (2009) in her research finds that some people wore chains around their bodies but in those cases, it was under the influence of the pir (p. 197). Frembgen (2008) also notes that other faqirs have expressed that they have worn the chains as a testimony to them being a 'slave of God'. Frembgen also notes that the wearing of such is related to a perception that it is supposedly protective of evil spirits, in addition to that of being a testimony to a specific bond to God or a pir (p. 135-6).
} 
people think that their prayers were accepted and rewarded by these pirs and thus become loyal to them.

As seen from the extract, the respondent says that he himself has never gone inside a tomb but has gone to shrines to offer fateha prayers. What is interesting about the respondent's reply is that although he himself objects to the idea of asking something for one's self, he believes that he has been prosperous because of other people going to the shrines to pray for him.

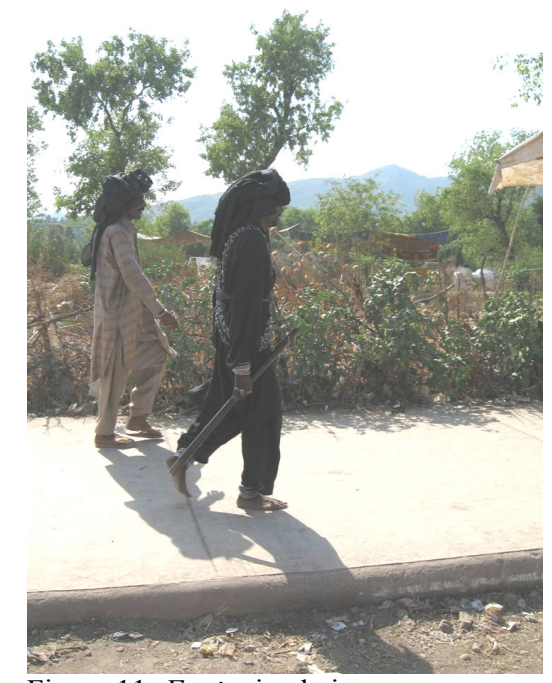

Figure 11. Faqirs in chains.

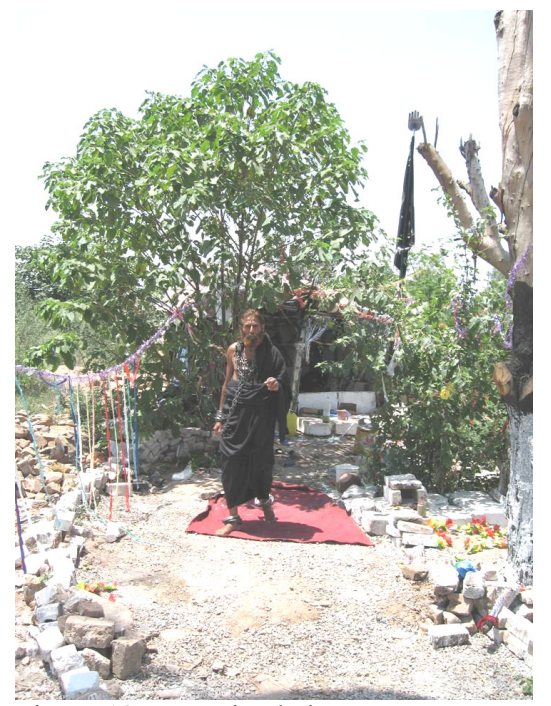

Figure 12. Faqir in chains.

The ambivalence described above is common. Indeed, although some of the practices described in the paragraphs above are considered unacceptable, illegitimate (najaiz), and commonly described as 'unIslamic' by the majority of Deobandis and Wahhabis, I have witnessed for myself that one may find people - either identifying themselves or otherwise revealing their sectarian affiliation as Deobandis or Wahhabis through dressing or other sectarian identification markers - doing so anyway. This is probably linked to the fact that although people may adhere to a particular sect, in practical terms, sectarian thinking or the 'absoluteness' of orthodoxy and 'folk Islam' is not as rigid and absolute as sometimes presented in popular or academic writings. Another important factor is that people 
in dire needs, as I have found, will resort to most available solutions in easing their situations.

I now turn to look at how respondents perceive the popularity of Sufism. The questions relating to the popularity of piri-muridi were meant to trigger responses regarding the (continued) role of pirs in politics and to assess the degree to which respondents had awareness of this.

Historically, the ancient khanqahs not only had success with the public. Rather, from an early age, the subcontinent's Muslim rulers recognized the political importance of the pirs, which was largely connected to the popular understanding that pirs had the power to intercede with God on people's behalf. The pirs were thus seen to have enormous influence over their subjects, which again could be used for political purposes. The Muslim rulers thus began following a policy of supporting them, for instance by allotting properties and financing the building of shrines, which helped to ensure political legitimacy for their government's reign. This system of supporting the pirs continued during British rule in India, which meant that in return, the pirs had their positions as influential people asserted. In contemporary Pakistan, this system of state patronage of the pirs still exists and it has even been a common practice that local politicians have used their connections to the shrines as 'references' in running for seats in elections. Pirs are still deeply intertwined in the political scene of contemporary Pakistan. ${ }^{65}$ As Ewing (1983: 257) explains:

...once Pakistan was created, they [the ulama] hoped to control the direction of the new country themselves, thus adding an additional element to the political scene, but the landowners and pirs continue to be major political forces with which any politician who wants to remain in power must still contend.

Talbot (1999: 37) for instance, notes that when Benazir Bhutto made her first visit to Lahore as Prime Minister on 25 December 1988, she went directly to the shrine of Data Ganj Baksh (p. 37). When Benazir Bhutto returned to Pakistan in 2007, the first thing she planned to do

\footnotetext{
${ }^{65}$ Aziz (2001: 7, 20); Buehler (1997: 306-7); Ewing (2004: 173, 190); Ewing (1983: 256-8); Frembgen (2008: 33, 59); Gardner (1993: 213); Gilmartin (1979: 494, 516); Hassan (1987: 558-9); Malik (2006: 31); Qadeer (2007: 204); Rozehnal (2006: 34, 45).
} 
was to visit a famous Sufi shrine in Karachi. The ruling government's security set-up for her return did not however permit her doing so. ${ }^{66}$

In Pakistan, pirs are identified with the particular geographical areas in which their shrines are located, and often the pir believed to have converted a tribe to Islam is the one pir that the tribe relates to and grants their allegiance. ${ }^{67}$ Elaborating on traditions of conversion and allegiance in pre-Islamic Pakistan, Ewing (1983: 255) says that:

The original conversion did not usually occur as a mass movement, but rather in the form of a political move, in which the tribal leader went to the khanqah (Sufi Center) of the saint and accepted conversion in the name of the saint... Even today [1983] allegiance to these traditional saints is not a matter of individual choice. A man is the follower of a certain saint because this is the saint of his tribe. The tie is political as well as spiritual. ${ }^{68}$

It is obvious, then, that pirs may exert power over their murids in many facets of life, including that of politics, as the tie bound between the two has more than one controlling factor. Indeed, the pir not only controls the murid in this life, he also has influence over the next phase. This influence and power is not least exploitable when the spiritual and the political fuses, as is common in Pakistani politics where many prominent political leaders hail from the spiritual powerhouses.

\section{'It used to be more popular in the past'}

During the latter half of 2007, I noticed that many politicians became actively engaged in trying to link themselves to some of the pirs: this

\footnotetext{
${ }^{66}$ Hassan (1987) adds an interesting and not much discussed aspect of the rulers' additional agenda in supporting the shrines; some sajjada nashins were granted large estates and in return they provided the rulers with military recruits for the state to use in case of political upheaval or war in the country. During Mughal rule, such military units were named lashkar-e-du'a (army of prayers) and were considered as important as regular army units were. For this system of military recruitment, the sajjada nashins were given substantial support in the form of land grants given either as waqf to the shrines, or as jagirs to individual pirs and sajjada nashins (p. 558).

${ }^{67}$ Ewing (1983: 254-5).

${ }^{68}$ In the Twin Cities, I often found people to choose a pir on their own initiative. Ewing (1983) also found the tendency among worshippers to locate pirs for themselves in another urban setting: Lahore (p. 255, footnote 4).
} 
was also the case of Benazir Bhutto. ${ }^{69}$ Part of the reason for including the question of whether Sufism was more popular now was thus a desire to see whether there existed any reflections on a potential role for the spiritual powerhouses in the election that was scheduled for autumn 2007 , which was eventually held in the spring of $2008 .^{70}$

Table 8. Popularity of Sufism now versus the past (Survey I).

\begin{tabular}{lrr}
\hline Is Sufism more popular now than before? & Total & Percentage \\
\hline a) Yes. & 129 & $27.16 \%$ \\
b) No. & 281 & $59.16 \%$ \\
c) Don't know/Refused to answer. & 65 & $13.68 \%$ \\
& $\mathbf{4 7 5}$ & $\mathbf{1 0 0 \%}$ \\
\hline
\end{tabular}

When asking about the perception of popularity of going to the shrines, keeping relations with the pirs, and going to 'urs (aspects of piri-muridi), respondents tended to say that it was more popular in the past, as seen from the table above. Usually, respondents compared popularity of the institution of piri-muridi with the times of independence, in 1947, which of course, few people have direct knowledge of. Thus, respondents would say that they had heard so from their parents etc. There was however one respondent who was old enough to recollect the time of independence: the same living pir (zinda pir) as quoted earlier. In the following, he recollects the pirs as role models for the people, their instrumentality in preaching and converting people to Islam, as well as their role in the Pakistan Movement's push for Pakistan:

When we turn the pages of history, we find these pirs as role models for others. By their character, they changed the lives of people and converted them to Islam. In our region, these pirs played a vital role in preaching Islam. They spent their entire lives on it. And a majority of people in the subcontinent believed in them, when this movement of

\footnotetext{
${ }^{69}$ Accompanied by Dr. Stig Toft Madsen and Prof. Dr. Hugh van Skyhawk (QeU), I was attending a meeting with two hereditary pirs at Golra Sharif when we suddenly were told to leave because of the visit of a VVIP (Very Very Important Person) - who the next day was identified as Benazir Bhutto.

${ }^{70}$ In describing the relationship of pirs in politics, Qureshi (2002) notes that there is, "...a triangle of zamindars, industrialists, and pirs who are also landowners... They provide patronage to their followers and develop the basis of patron-client relationship. The tenants and the rural masses serve as "vote bank" for the landowning elites" (p. 17).
} 
independence started. These pirs pushed their murids in this movement. In older days, people were ignorant [jahil]. There are so many examples. People used to bury their daughters alive.

As seen from the table below, the ones arguing that Sufism had achieved greater popularity in recent times saw this neither in connection with elections nor in the political context in general. Most of the respondents who argued that Sufism had gained popularity argued that the reason behind this was that in contemporary Pakistan, more people than in the past are living under terrible conditions and thus need comfort from the pirs.

Table 9. Why is Sufism more popular now than in the past? (Survey I).

\begin{tabular}{lrr}
\hline $\begin{array}{l}\text { If you believe Sufism is more popular now than before, } \\
\text { why is it so? }\end{array}$ & Total & Percentage \\
\hline \multicolumn{1}{c}{ Of total respondents } \\
$\begin{array}{l}\text { a) Elections are coming up - Sufi orders play an important } \\
\text { role in the electoral process... }\end{array}$ & 10 & $2.11 \%$ \\
$\begin{array}{l}\text { b) People are more scared and need comfort from } \\
\text { religious/spiritual persons. }\end{array}$ & 25 & $5.26 \%$ \\
$\begin{array}{l}\text { c) People often go there to get help (e.g. to get cured from } \\
\text { diseases etc.). }\end{array}$ & 80 & $16.84 \%$ \\
d) Don't know/Refused to answer. & 14 & $2.95 \%$ \\
& $\mathbf{1 2 9}$ & $\mathbf{2 7 . 1 6 \%}$ \\
\hline
\end{tabular}

\section{'People do not want to destroy their own destinies'}

The politician's power comes from the ballot, the General's from the gun, the pir's from the grave. The first speaks in the name of the people, the second in the name of the Army, the third in the name of the dead. (Aziz 2001: 62)

For a long time the pirs of Pakistan have taken advantage of the powers inherited through their ancestors. As Aziz notes in the quote above, their powers are also manifested through an eternal bond to the dead (original) pirs, which they often take advantage of. Often, as Weinbaum (1996: 650) argues, the political influence of the pirs is so strong that, "Election to the National Assembly is virtually assured for those considered a living saint by their constituents." Most respondents, however, see no role for the pirs in politics. However, 
when confronted with different politicians' names and their affiliations with shrines and tariqas, respondents tend to recognize the link between politics and pirs. Then the respondents would mostly argue that the spiritual institution should not be mixed with politics. Regarding this, it is likely that the influence of pirs in politics is much less in urban areas such as the Twin Cities than in rural areas, where the pirs have traditionally played a key role in politics.

Table 10. Sufi networks' role in electoral process (Survey I).

\begin{tabular}{lrr}
\hline $\begin{array}{l}\text { Are Sufi networks important for the electoral process of } \\
\text { Pakistan? }\end{array}$ & Total & Percentage \\
\hline a) Yes. & 62 & $13.05 \%$ \\
b) No. & 316 & $66.53 \%$ \\
c) Don't know/Refused to answer. & 97 & $20.42 \%$ \\
& $\mathbf{4 7 5}$ & $\mathbf{1 0 0 \%}$ \\
\hline
\end{tabular}

A small number of respondents did however have clear visions of how pirs are active in politics; these are mostly respondents who have rural backgrounds and have witnessed for themselves how the pirs manipulate local politics and take advantage of their so-called votebanks. One such respondent, the same 45-year-old former PIA employee referred to earlier, emphasized the spiritual power the pirs have over their subjects, extending it into politics. This is what the respondent said about pirs and politics:

Well, I think it is called voter banks. They [the pirs] are paid to support someone [politician], some pirs keep huge voter banks, selling them to the largest bidder. Still, the people love them, whether they do something good or not. The thing is that people do not want to destroy their own destinies (qudrat). This is important.

As it is widely believed that pirs have the ability and power to control peoples' destinies, qudrat, it thus seem reasonable that the same people will do almost anything the pirs will tell them, including voting for their favored political party. To this, there is very little consciousness among respondents. As seen from the table below, only slightly more than $5 \%$ linked this type of power with the Sufi networks in Pakistan: 
Table 11. How Sufi networks have a role in the electoral process (Survey I).

\begin{tabular}{|c|c|c|}
\hline $\begin{array}{l}\text { How are Sufi networks important for the electoral process } \\
\text { of Pakistan? }\end{array}$ & Total & Percentage \\
\hline \multicolumn{3}{|l|}{ Of total respondents } \\
\hline $\begin{array}{l}\text { a They (pirs) have power over the people giving } \\
\text { advice/blessings, it would be unwise to go against their advice } \\
\text { - if they advise you to vote for someone. }\end{array}$ & 25 & $5.26 \%$ \\
\hline b) They are often in political positions themselves. & 30 & $6.32 \%$ \\
\hline c) Don't know/Refused to answer. & 7 & $1.47 \%$ \\
\hline & 62 & $13.05 \%$ \\
\hline
\end{tabular}

These numbers then, are different than what would be expected. In explaining the fear of challenging the power of the pirs, Frembgen (2008: 31) argues that, "The saint's power is often experienced as ambivalent: As long as his devotees are obedient and venerate him in the proper way, the holy man is benevolent and rewarding, but fear and punishment are certain for those who do not follow his commands."

\section{Conclusion}

The system of piri-muridi is still thriving, representing an important aspect of Muslim religious experience in the Twin Cities. In the Twin Cities, there are numerous pirs at shrines, as well as independent dervishes and faqirs, with whom many people have a reciprocal relationship. Although some question the authority and authentic credentials of the institution of piri-muridi, many regard Sufism as an integral part of Islam and relate to it in their lives. Firstly, this is related to perceptions that the alternative assistance provided by the pirs, through their ability to perform miracles (karamat) and extend their blessing (baraka) to their subjects, is the solution to many of their problems and that they indeed can be cured of illnesses or otherwise experience fewer problems in their lives. Secondly, respondents describe the notion of keeping up a relationship with a pir as a substitute to compensate for their lack of knowledge of Islam: thus, in a sense the pir becomes the guarantee of the murid's religious obligations. Thirdly, it is fair to assume that the system of reciprocity between the pir and the murid is still kept intact, as it is perceived to be in line with the families' expectations and part of the belief system 
as inherited and propagated through the lineages and (they) thus do not want to upset their family's destiny (qudrat). Finally, there is the aspect of the cultural and religious fusions that have come to influence Islam in Pakistan, which are sometimes difficult to allocate to one specific sect or school of law, which incorporate some practices, including Sufism, while rejecting others.

At the same time, there is a growing awareness and focus among respondents that some practices associated with Sufism are unIslamic and should be rooted out. Practices such as dhammal and consuming drugs or alcohol at shrines are widely held in contempt. On the other hand, there is a dualism in that while respondents condemn certain practices and rituals as 'un-Islamic', they still actively seek the shrines and the pirs and try to reap the possible benefits that the institutions can provide. The issue is further complicated by a notion of privacy, or even embarrassment, in the sense that most respondents perceive their relationships with the shrines as a personal matter, not even telling family members of their devotion to them, and are thus hesitant to reveal information on the subject.

While it is likely that (some) pirs and shrines have become more conservative and orthodox themselves, there is an increased rhetorical emphasis on 'Islamic identity', or the 'true Islam' - free of pre-Islamic ideas, practices, and values. This, I will argue, leads people into projecting a more orthodox Islam at the cost of traditional 'folk Islam', although many people might still adhere to practices associated with Sufism through the shrines and believe in the miracles (karamat) and ability to give blessings (baraka) of pirs as well as independent dervishes and faqirs. The orthodox alternative is promoted and filled mainly by Deobandi and Wahhabi organizations, which have started to be more outward in their preaching and missionary activities, thus reaching out to more people. Faith-based organizations of different affiliations, including the Jama'at udDawaa, are also active in the Twin Cities, primarily as providers of welfare, which they often use as a pretext for gathering people to their congregations or otherwise use to promote their line of thinking.

The orthodox movements offer an alternative to the mystical, secretive, and difficult to understand Sufism as propagated by the Barelvis. It is a common perception that the old pirs, the institution of piri-muridi, has changed in the sense that the system of reciprocity has 
turned into a one-way street, where only the murids commit themselves and their resources, and the pirs have stopped giving anything back while still behaving as 'feudal lords'. Nonetheless, many devotees express that they do indeed get something back. The orthodox movements, on the other hand, present themselves as equals, playing the 'international brotherhood of Muslims, card, using words as such brother (bhai) and approaching people with utmost respect, which clearly has an emotional effect on the many deprived, as well as the middle and higher classes, of the Twin Cities. The trend towards orthodoxy may also be related to increased access to technology, especially among the many 're-emigrants' of Islamabad, as discussed earlier. Literacy rates and education in general are also factors that can help explain a shift towards orthodoxy, because as people become more literate, they explore religious literature for themselves, turning to the Qur'an and hadiths because they are tired of having mullahs and pirs telling them what their religion consists of.

Finally, the increased levels of orthodoxy may also be seen as a response to western modernization, in which there is a transfer of loyalty from the traditional 'folk Islam' towards a purist and scripturalist version of Islam. In relating to this, reaching out towards a more purist (orthodox) form of Islam is also seen as an aspect of indigenous modernization in itself, for instance by seeking out and eliminating practices which are not found in the Qur'an and Sunnah. According to J. B. Tamney, modernization is associated with religious purification. Tamney argues that modern people differentiate themselves from the traditional ('folk Islam') in the sense that they practice a purer form of religion after having gone through a (purification) process where they deliberately seek out and eliminate elements and practices, the inconsistencies, which cannot be found in scriptures: the original sources (Qur'an and the Sunnah). In this sense, Tamney's argument can thus be seen as that of religious purification, as found among Islamists, as one aspect of modernization in itself. ${ }^{71}$ This in turn may help explain why piri-muridi of the Twin Cities may have become more orthodox - as a way of 'fitting the traditional with the modern.'

\footnotetext{
${ }^{71}$ J.B. Tamney's arguments found in Hassan (2004: 14). Hassan finds some support for this theory in his own empirical work (Hassan 2004: 15).
} 


\section{References}

Abbas, Hassan (2005) Pakistan's Drift into Extremism: Allah, the Army and America's War on Terror. New York: M. E. Sharpe, Inc.

Abbas, Sohail (2007) Probing the Jihadi Mindset. Islamabad: National Book Foundation.

Ahmad, Sadaf (2008) 'Identity Matters, Culture Wars: An Account of Al-Huda (re)Defining Identity and Reconfiguring Culture in Pakistan', Culture and Religion, 9:1, pp. 63-80.

Ahmed, Akbar S. (2003) [2002] Discovering Islam: Making Sense of Muslim History and Society. (Revised edition) New Delhi: Roli Books Pvt Ltd

Aziz, K.K. (2001) Religion, Land and Politics in Pakistan: A Study of Piri-Muridi. Lahore: Vanguard Books.

Buehler, Arthur F. (1997) 'Currents of Sufism in Nineteenth- and Twentieth-Century Indo-Pakistan: An Overview', The Muslim World, Vol. LXXXVII, No. 3-4, July-October 1997, pp. 299314.

Cohen, Stephen Philip (2005) The Idea of Pakistan. Lahore: Vanguard Books.

Ewing, Katherine Pratt (2004) 'The Sufi and the Mullah: Islam and Local Culture in Pakistan.' In Kennedy, Charles H.; McNeil, Kathleen; Ernst, Carl; Gilmartin, David (eds.) (2004) [2003] Pakistan at the Millennium. Karachi: Oxford University Press. (1990) 'The Dream of Spiritual Initiation and the Organization of Self Representations among Pakistani Sufis', American Ethnologist, Vol. 17, No. 1 (Feb., 1990), pp. 56-74.

(1983) 'The Politics of Sufism: Redefining the Saints of Pakistan', Journal of Asian Studies, Vol. XLII, No. 2, February 1983, pp. 251-68.

Frembgen, Jürgen Wasim (2008) Journey to God: Sufis and Dervishes in Islam. Karachi: Oxford University Press. 
Gallup Pakistan/Gilani Research Foundation. Public

Opinion/Perception Poll. 3 February 2010. 'Views on Evil Eye \& Magic'. Retrieved from: http://www.gallup.com.pk/Polls/0302-10.pdf. Last accessed: 29 April 2010.

29 January 2010. 'Views on Visiting the Graves of Famous Saints'. Retrieved from: http://www.gallup.com.pk/Polls/29-0110.pdf. Last accessed: 29 April 2010.

- 16 February 2007. 'Views of Black Magic and Tawiz ganda'. Retrieved from:

http://www.gallup.com.pk/Polls/press16feb07.pdf. Last accessed: 29 April 2010.

Gardner, Katy (1993) 'Mullahs, Migrants, Miracles: Travel and Transformation in Sylhet', Contributions to Indian Sociology, 27:2, 1993, pp. 213-35.

Gellner, Ernest (1978) [1968] 'The Pendulum Swing Theory of Islam', pp. 127-138, in Robertson, Roland (ed.) (1978) [1969] Sociology of Religion: Selected Readings. Middlesex: Penguin Books Ltd. Originally published as 'Pendulum Swing Theory of Islam', Annales de Sociologie Marocaines, 1968, pp. 5-14.

Gilmartin, David (1979) 'Religious Leadership and the Pakistan Movement in the Punjab', Modern Asian Studies, Vol. 13, No. 3, pp. 485-517.

Hassan, Riaz (2004) [2002] Faithlines: Muslim Conceptions of Islam and Society. Karachi: Oxford University Press.

(1987) 'Religion, Society, and the State in Pakistan: Pirs and Politics', Asian Survey, Vol. XXVII, No. 5, May 1987, pp. 55265.

Iqbal, Dr. Javid (2007) Islam and Pakistan's Identity. Lahore: Sang-eMeel Publications.

Kazimi, M. R. (2009) A Concise History of Pakistan. Karachi: Oxford University Press.

Malik, Iftikhar H. (2006) Culture and Customs of Pakistan. Westport: Greenwood Press. 
Mohammad, Aminah (2002) 'The Diversity of Islam', pp. 221-234, in Jaffrelot, Christophe (ed.) (2002) A History of Pakistan and its Origins. Translated by Gillian Beaumont. London: Anthem Press.

Pirani, Farida (2009) 'Therapeutic Encounters' at a Muslim Shrine in Pakistan: An Ethnographic Study of Understanding and Explanations of Ill Health and Help-Seeking among Attendees. $\mathrm{PhD}$-thesis submitted to Middlesex University August 2009.

Qadeer, Mohammad Abdul (2007) [2006] Pakistan: Social and Cultural Transformations in a Muslim Nation. New York: Routledge.

Qureshi, Prof. Muhammad Siddique (2002) Political Culture in Pakistan. Islamabad: Dost Publications.

Rahman, Fazlur (1984) [1982] Islam \& Modernity: Transformation of an Intellectual Tradition. Chicago: The University of Chicago Press.

Rahman, Tariq (2007) 'Pluralism and Intolerance in Pakistani Society: Attitudes of Pakistani Students towards the Religious 'Other', pp. 122-151, in Shafqat, Saeed (ed.) (2007) New Perspectives on Pakistan: Visions for the Future. Karachi: Oxford University Press.

Roy, Olivier (2002) 'Islamic Radicalism in Afghanistan and Pakistan', United Nations High Commissioner for Refugees (UNHCR) Emergency and Security Service, WRITENET Paper 06/2001, January 2002.

Rozehnal, Robert (2006) 'Faqir or Faker": The Pakpattan Tragedy and the Politics of Sufism in Pakistan', Religion, 36 (2006), pp. $29-47$.

Talbot, Ian (1999) Pakistan: A Modern History. Lahore: Vanguard Books. (2004) 'Back to the Future?'. In Kennedy, Charles H.; McNeil, Kathleen; Ernst, Carl; Gilmartin, David (eds.) (2004) [2003] Pakistan at the Millennium. Karachi: Oxford University Press. 
(2005) 'Understanding Religious Violence in Contemporary

Pakistan', pp. 145-164, in Kaur, Ravinder (ed.) (2005)

Religion, Violence and Political Mobilisation in South Asia.

New Delhi: Sage Publications.

van der Veer, Peter (1992) 'Playing or Praying: A Sufi Saint's Day in Surat', The Journal of Asian Studies, Vol. 51, No. 3 (Aug., 1992), pp. 545-564.

Verkaaik, Oskar (2007) 'Ethnicizing Islam: 'Sindhi Sufis', Muhajir Modernists' and 'Tribal Islamists' in Pakistan'. In Shafqat, Saeed (ed.) (2007) New Perspectives on Pakistan: Visions for the Future. Karachi: Oxford University Press.

(2004) 'Reforming Mysticism: Sindhi Separatist Intellectuals in Pakistan', IRSH, Vol. 49, 2004, Supplement, pp. 65-86.

Weinbaum, Marvin G. (1996) 'Civic Culture and Democracy in Pakistan', Asian Survey, Vol. 36, No. 7, Jul 1996, pp. 639-654.

Zaman, Muhammad Qasim (2004) [2002] The Ulama in Contemporary Islam: Custodians of Change. Karachi: Oxford University Press. 